\title{
Projeto de Primeiro Mundo com conhecimento e trabalho do Terceiro?
}

\section{RUT DE QUADROS CARVALHO}

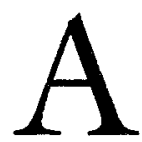

$s$ economias capitalistas estão em meio a uma mudança estrutural, marcada por intensificação dos fluxos de comércio e investimentos externos, reorganização dos mercados, acirramento da competição e consolidação do poderio econômico do Japão e da Comunidade Européia em desafio à hegemonia americana. Uma das faces de tal mudança é a impressionante aceleração do progresso técnico, já popularizada como revolução tecnológica. Tal aceleração é resultado do salto dos investimentos dos países de industrializaçáo avançada em atividades científicas e tecnológicas, visando ao aproveitamento de oportunidades abertas pelo progresso científico para o desenvolvimento de novas tecnologias.

Nesse quadro, a difusão de nova tecnologia genérica - a microeletrônica - está na raiz da re estruturação em curso na indústria e nos serviços, em escala global. Ela permitiu, pela primeira vez na história da indústria, associar flexibilidade à automação, ampliando bastante o escopo de aplicaçáo da última. A nova base técnica tem contribuído para um crescimento sem precedentes do nível de integração das mais diversas funções produtivas, e entre mercados através das fronteiras. Tais mudanças também se fazem sentir no crescimento extraordinário da prestaçáo de serviços ao produtor. Talvez mais importante, a aceleração do progresso técnico tem aberto novos mercados a setores emergentes, entre os quais o próprio complexo eletrônico, em que a incorporação de avanços científicos - e da própria atividade científica - constitui a base para o lançamento de inovaçóes responsáveis pela reestruturação das demais indústrias.

Entre os vários aspectos da transformação social associada a estes fenômenos, um dos mais interessantes - talvez verdadeiramente revolucionário - é a mudança da natureza do trabalho e a percepção de seu papel pelas gerências, sobretudo do trabalho produtivó na indústria $\mathrm{e}$ 
nos serviços. Muitos autores no campo da economia e da sociologia, que basearam suas análises na realidade dos países mais desenvolvidos, têm apontado com ênfase para uma radical revisăo do papel do trabalho nas estratégias de produção das empresas. $O$ trabalho estaria deixando de scr percebido - e utilizado - exclusivamente como um componente de custos, para tornar-se, adicionalmente, fonte de recursos. A difusão das novas tecnologias de produção, das novas técnicas de gestão a elas associadas e progressiva sofisticaçăo tecnológica dos produtos exigiriam a recuperação da inteligência da produfão, vista como ruído indesejável dentro do dogma taylorista até então dominante (1).

As implicaçóes dessa mudança para a quantidade e a qualidade do emprego, bem como para as práticas de gestão do trabalho das empresas seriam profundas. Entre elas estariam a tendência à reprofissionalização do trabalho industrial, o aumento do grau de qualificaçáo médio da força de trabalho, o aumento significativo do nível de escolaridade dos trabalhadores e o desenvolvimento de estratégias de gestáo do trabalho que visam, sobretudo pela estabilizaçáo do vínculo de emprego, a obter a cooperação dos trabalhadores.

Em total contraste com tais tendências, vivemos em um país no qual a estrutura ocupacional da indústria é extremamente polarizada entre grande massa de trabalhadores semi-qualificados ou sem qualificação e parcela bem menor composta por trabalhadores qualificados, técnicos de nível médio e superior e pessoal de direção. Metade dos trabalhadores empregados na indústria (setor formal) náo foram além de quatro anos de estudos. O salário médio náo chega a quatro salários mínimos e a rotatividade da mão-de-obra é altíssima (acima de $50 \%$ no setor formal da indústria, na segunda metade da década passada). Estes números indicam não serem desenvolvimento e aproveitamento da inteligencia da produfãoo ponto forte da indústria brasileira. Embora haja significativas exceçóes setoriais, o trabalho com pouca qualificação, barato e descartápel continua sendo a base na qual se sustenta a maior parcela das atividades do setor secundário no Brasil.

O objetivo deste artigo é documentar e discutir os principais determinantes de tal contradição, representada pela continuidade, no Brasil, de padrão predatório de uso do trabalho em um momento no qual as economias mais avançadas do mundo promovem a valorização do trabalho. No próximo tópico procurar-se-á mostrar como a aceleraçĩo do progresso técnico está intrinsecamente ligada ao processo de revisão do papel do trabalho nas economias mais avançadas. A capacidade de inovar é ativo ainda mais decisivo - e um bem náo livremente disponível no mercado - nas condiçóes de competição que se delineiam neste 
final de século. Esta capacidade desenvolve-se como processo de àcumulação de conhecimentos dentro das firmas, em que a contribuição do trabalho, em todos os níveis e esferas, é um dos fatores mais importantes. A ampliacão do conteuido inovativo do trabalbo, em maior ou menor grau, é o eixo comum da mudança dos processos de trabalbo industriais. A percepção dessa importância está na raiz da revisão das políticas de gestâo e uso do trabalho nesses países. Alguns dados são apresentados a fim de ilustrar essas tendências.

A situação do Brasil será discutida posteriormente, no tópico $O$ contraste da situação brasileira. Procuro argumentar que as características do uso do trabalho na indústria brasileira estáo associadas ao contexto de industrialização marcado, estruturalmente, pela baixa capacitação tecnológica e, conjunturalmente, pela defasagem na difusão de novas tecnologias e novos métodos de organização da produção. São apresentados indicadores dessa fragilidade tecnológica, ainda mais acentuada nas empresas privadas do setor industrial. A baixa capacitação e a defasagem tecnológica são os determinantes imediatos da predominância de processos de trabalho ainda inspirados fundamentalmente por princípios tayloristas/fordistas, a despeito do crescente número de experiências de mudança - algumas superficiais - que vêm ocorrendo em nível das firmas. São apresentados alguns indicadores relativos à estrutura ocupacional, nível de escolaridade, remuneração e rotatividade da força de trabalho industrial, que procuram caracterizar o que chamo de padráo predatório de uso do trabalho. Este é o padráo prevalecente, apesar de publicamente criticado pelas lideranças empresariais brasileiras mais modernas.

Embora o tratamento dado neste artigo privilegie o setor secundário como um todo, exemplos setoriais, baseados em pesquisa do autor, sáo introduzidos a fim de enriquecer os argumentos. A principal conclusáo do artigo refere-se ao nosso atraso no que diz respeito ao perfil da força de trabalho industrial, e ao uso que dela se faz, estar profundamente associado à fragilidade tecnológica da indústria brasileira. A superaçăo de tal situação requer mudanças significativas nas políticas empresariais e governamentais.

\section{A aceleração do progresso técnico e a revalorização do trabalho nas economias capitalistas avançadas}

$O$ aumento dos investimentos em PơD e a revolução Microeletrônica

Ainda que discordando na interpretaçĩo do fenômeno, a maior 
parte dos pesquisadores parece concordar com a existência de evidência de terem sido as duas últimas décadas do século $\mathrm{XX}$ marcadas pela aceleração da taxa de acumulação de conhecimentos científico e tecnológico.

A história do progresso técnico neste século foi singularizada pela internalizaçăo de atividades científicas e tecnológicas conduzidas por grandes empresas ( $P \& D$ cativo), a qual representou mudança estrutural na natureza e nos mecanismos de difusão do progresso técnico. Embora introduzida inicialmente pelos setores químico e eletroeletrônico, tal inovaçăo social (Freeman \& Soete, 1982) difundiu-se em outros setores industriais. A tal ponto que as trajetórias de inovaçáo tecnológica mais importantes nas economias capitalistas passaram a ter caráter cumulativo, endógeno às empresas e apropriável por elas (2); a partir de meados dos anos 70 , esse modelo de geração e difusão de tecnologia ganha peso ainda maior nas economias capitalistas avançadas.

A crise dos anos 70 levou as empresas a intensificarem a procura de novos meios para aumento de produtividade e desenvolvimento de novos produtos e mercados. Essa busca realizou-se, sobretudo, por exploraçáo de oportunidades tecnológicas oferecidas pelo avanço das tecnologias da informação, possibilidades criadas pelo desenvolvimento científico na 7 biologia molecular e progresso da química relativamente a novas especialidades (produtos) com altíssimo valor agregado. $O$ que nos importa reter é ter sido essa busca de novas trajetórias, em grande medida, resultado da intensificação dos investimentos e das atividades de $P \& D$ (públicas e privadas) nas economias avançadas. Como se observa na tabela 1 , a participação dos investimentos em P\&D no PIB de economias como Japão e EUA, e mesmo de economias de industrialização recente como República da Coréia e Taiwan, cresceu significativamente nos anos 80. O mesmo náo se pode dizer do Brasil.

Os dados referidos náo refletem a totalidade do esforço tecnológico realizado por essas economias, já que deixam de contabilizar as práticas inovativas não formalizadas como $P \& D$ nos planos da engenharia e da produçáo. Ainda assim, o significativo crescimento dos investimentos em $P \& D$ é bom indicador do aqui denominado aceleraf̧ão do progresso técnico. A competiçáo, com base na inovação tecnológica, transformou-se em fator dominante em muitas indústrias e em muitos serviços, e a intensificaçăo das atividades tecnológicas - incluindo $\mathrm{P} \& \mathrm{D}$ - é o elemento essencial deste tipo de competição. $O$ esforço de acumulação de conhecimento tecnológico pelas empresas das economias mais dinâmicas pode ser examinado pelo elevado percentual da participaçáo 
Investimentos em P\&D como Proporção do PIB cm Países Selecionados 1980/1985

\begin{tabular}{lccc} 
País & 1980 & 1985 & $\begin{array}{c}\text { Participação do } \\
\text { Sctor Produtivo } \\
(1988)\end{array}$ \\
Brasil* & 0.60 & 0.60 & $7 \%$ \\
Coréia & 0.58 & 1.59 & $81 \%$ \\
Taiwan & 0.72 & 1.06 & - \\
EUA & 2,57 & 3,49 & $51 \%$ \\
Japão & 2.63 & 3.49 & $80 \%$ \\
\hline
\end{tabular}

Fonte: Dahlman (1989) e Brasil/SCT (1991)

* Estes dados baseiam-se em Brasil/SCT (1991) sobre gastos em C\&T em 1988, tomando-os como proxy dos investimentos em P\&D.

do setor produtivo nos gastos em P\&D (v. tabela 1, na qual, mais uma vez, a situaçáo do Brasil constitui exceção).

Aspecto importante desse fenômeno é o crescimento da participação das atividades de $P \& D$ na produçáo de valor agregado não se dar exclusivamente nas indústrias de alta tecnologia, nas quais a utilização da ciência como força produtiva tem se dado em escala sem precedentes. Nas economias avançadas, essa tendência também está presente em muitas das indústrias maduras (3).

A principal fonte, e correia de transmissáo, da aceleraçáo do progresso técnico encontra-se no desenvolvimento e na difusão abrangente da Tecnologia da Informação (TI), compreendendo a microeletrônica, a informática e demais tecnologias nela baseadas. Sua ampla potencialidade para afetar a estrutura de muitos dos produtos e serviços existentes, bem como a maneira de produzi-los e vendê-los, juntamente com os novos produtos e serviços trazidos ao mercado, constitui o que leva muitos analistas a considerarem a TI como revolucionária ou base de uma mudança de paradigma tecnológico (4). Năo caberia aqui discussáo detalhada das implicaçóes econômicas desse fenômeno. Apenas al- 
guns de seus aspectos centrais, que afetam mais diretamente a economia da produção e, portanto, do trabalho, serão a seguir sintctizados.

Em primeiro lugar, a microeletrônica abriu caminho para o desenvolvimento de grande número de novas indústrias e novos serviços (equipamentos de processamento de dados, automaçăo industrial, serviços de software e processamento de dados, entre outros) e daquelas indústrias cujos produtos tiveram sua base técnica transformada pela nova tecnologia (telecomunicações, instrumentação, eletrônica de consumo etc.). Esse crescimento foi de tal ordem que, em algumas economias avançadas, o complexo eletrônico já se encontra entre os primeiros colocados em termos de valor agregado pela produçăo (5). O crescimento do complexo eletrônico tem profundas implicaçóes para a estrutura industrial e para a base de recursos humanos dos países avançados porque, em sua maior parte, trata-se de indústrias e serviços de alto valor agregado, intensivos em conhecimento científico e tecnológico, que investem pesadamente em $\mathrm{P} \& \mathrm{D}$.

Em segundo lugar, a difusão dos meios técnicos produzidos pelo complexo eletrônico abriu caminho para a reorganizaçáo técnica e organizacional nos setores considerados maduros, a tal ponto que, em setores como o automobilístico, fala-se de uma de-maturafáo da indústria. Produtos têm sido inteiramente redefinidos, para tornarem-se inteligentes. A automaçáo programável permitiu associar flexibilidade à automação, acelerando possibilidades de mudança de modelos e designs, diminuindo exigências de escala, e ampliando os meios técnicos de controle da qualidade. Foram derrubadas barreiras técnicas e a mecanização pôde ser estendida a áreas e tarefas até entáo impensáveis, como a montagem e o armazenamento.

No entanto, diferentemente da onda de automação dos anos $\mathbf{5 0}$, os meios da automação programável não se restringiram à produção, mas ampliaram possibilidades de integraçăo organizacional. Dada a capacidade de armazenar, processar e difundir informaçóes com base no mesmo meio técnico, a nova tecnologia viabilizou integração horizontal sem precedentes, compreendendo desde o desenvolvimento do produto até os serviços de venda e atendimento pós-consumo, passando pela produção.

Em terceiro lugar, a TI tem servido ela mesma como meio técnico crucial para a intensificaçáo do progresso científico e tecnológico. Os desenvolvimentos recentes no campo da astronomia e da engenharia genética seriam inimagináveis sem os recursos de uma potente base computacional. De maneira análoga, o projeto e a engenharia assistidos por 
computador $\mathrm{e}$ instrumentação eletrônica ampliaram os horizontes $\mathrm{c}$ rcduziram drasticamente o lead-time para desenvolvimento de novos produtos (incluindo o desenvolvimento de semicondutores). Nestc sentido, pode-se dizer que o desenvolvimento da TI é retroalimentado.

\section{Implicafóes da acelerafão do progresso técnico para o processo de trabalho capitalista: atenuafäo da divisão do trabalho e crescimento de seu conterido inopativo}

As tendências do progresso técnico retro comentadas implicam mudanças radicais nos processos de trabalho das atividades produtivas nas economias mais avançadas. Embora não seja simples compreender essas mudanças a partir de um enfoque macro, quando há tantas especificidades setoriais, acredito ser possível generalizar e distinguir alguns traços marcantes. Neste sentido, três traços ou tendências básicas de mudança são aqui destacados.

- Em primeiro lugar, o crescimento da participaçáo das atividades de inovação - em particular de $\mathrm{P} \& \mathrm{D}$ - no valor agregado pela produçáo industrial, coloca em cheque o conceito de processo de trabalho, especialmente quanto às fronteiras usualmente estabelecidas pela literatura ao restringir o conceito ao que ocorre no chăo-dafábrica (shopfloor). Do ponto de vista da produção de valor, atividades consideradas fora da produçăo, como $P \& D$, engenharia e serviços após venda, sua participação relativa tem sido substancialmente ampliada. A separaçáo entre inovar e produzir começa, conceitualmente, a deixar de fazer sentido. Nas condiçóes do capitalismo contemporâneo, produzir é cada vez mais "produzir inovafáo" .

Certamente, essa generalização merece ser qualificada em função das distintas realidades setoriais, sobretudo no que diz respeito às diferentes características da geração e difusáo de tecnologias. Năo cabe, aqui, aprofundamento em qualificação desse tipo, mas mencionar alguns casos concretos, objetivando fortalecer o argumento. Para indústrias situadas na fronteira tecnológica, e que já constituem parcela significativa da produção nas economias avançadas, produzir avanços tecnológicos é o estágio crucial do seu ciclo produtivo, assim como a inovação é o principal produto ou serviço que vendem. Quanto mais um setor ou firma for intensivo em ciência, isto é, quanto mais sua posição competitiva dependa do contínuo desenvolvimento de tecnologias apropriáveis derivadas de avanços científicos, mais o centro de gravidade de seu ciclo produtivo tende 
a se deslocar para suas atividades de inovação. Não obstante, mesmo em indústrias mais dependentes de outros fatores competitivos, como escala e produtividade do trabalho, mas com investimentos elevados em P\&D (por exemplo, nas indústrias de máquinas), as atividades ligadas à inovação de produto tornam-se cada vez mais importantes, como resultado da fragmentação dos mercados e da maior importância da produção costumizada.

No entanto, tal tendência não deve ser entendida como perda da importância estratégica da produção. Ao contrário, o mesmo processo que leva a ampliar o conceito de produçáo para incorporar a produfão da inovação, atua no sentido de ampliar o conceito de inovaçăo para incorporar a inovaçăo que nasce no chão-da-fábrica. Em indústrias cuja competiçáo está mais centrada na inovação de produto, a força de trabalho na produção tem tarefas decisivas relacionadas com implementaçáo, teste e correçăo de novos processos $\mathrm{c}$ produtos. $O$ mesmo argumento vale com relação à contribuição do conhecimento acumulado no chão-da-fábrica, para empresas que adotam automação programável poderem se beneficiar das oportunidades oferecidas por esta tecnologia quanto à aceleraçáo da taxa de inovação de produto e processo, como argumentado por Hoffman (1988). A idéia de fábrica-laboratório (Freeman, 1988), nascida a partir de uma pesquisa em indústrias japonesas de bens de consumo eletrônicos, sintetiza bem a noção de que a fábrica é o local privilegiado dos testes de projetos de novos produtos, cujos ciclos de vida são cada vez menores.

- A segunda tendência de mudança nos processos de trabalho industriais modernos está relacionada com a difusão da automaçáo programável. Sobretudo em setores que, antes da atual onda de automação, eram caracterizados por processos de trabalho predominantemente manuais ou semi-automatizados (por exemplo, nas indústrias envolvendo montagem em série), está havendo mudança na natureza e no conteúdo do trabalho na produção. Para além da destruição/criação de empregos, a própria natureza do trabalho vivo está sendo modificada no curso do presente salto da automação. $O$ trabalho manual direto - em sua maior parte fragmentado e pouco qualificado - está sendo progressivamente eliminado, emergindo em seu lugar tarefas de monitoramento e supervisão de sistemas automatizados, de natureza totalmente distinta (Carvalho, 1992b). Em processo semelhante ao já ocorrido com as indústrias em fluxo contínuo nos anos $\mathbf{5 0}$ (a exemplo da indústria química), as novas tarefas requerem visão mais integrada do processo produtivo. En- 
quanto o trabalho convencional na produção não automatizada é preso a um posto de trabalho fragmentado, estreitamentc planejado e ritmado pelas máquinas, nos novos sistemas de produção o trabalho é mais integralizado: o trabalhador é encarregado de supervisionar conjuntos de equipamentos integrados.

Enquanto na produção convencional o trabalho direto está fundamentalmente ligado à manipulação e transformação de materiais, nos sistemas baseados na automação programável a principal tarefa da produção poderia ser sintetizada como manter o sistema funcionando (e, como já visto, sob intensa pressáo por melhora de qualidade $e$ introdução de inovaçóes) (Carvalho, 1992b). Deste ponto de vista, a antiga distância entre $o$ trabalho de produção e o de manutenção, cujo objetivo final é exatamente o de manter o sistema funcionando, diminui significativamente. A necessidade sempre presente de reduzir o downtime em sistemas automatizados, associada às pressóes pela racionalização do uso do trabalho, têm levado a diversas formas tentativas de integração de tarefas de manutenção com as de produção nos países mais avançados.

Cabe ainda mencionar que o trabalho em sistemas automatizados abrange conteúdo intrinsecamente relacionado com o processo de inovaçáo tecnológica. Não se trata apenas da maior frequiência de introduçáo de novos produtos, já comentada, possibilitada pela extrema flexibilidade da nova tecnologia e que tem no teste da produção, laboratório indispensável para aperfeiçoamentos. Trata-se também de os sistemas automatizados serem sistemas abertos, permanentemente em evoluçáo, valendo-se muito do feed-back que vem do chão da fábrica.

- Finalmente, mas não menos importante, a terceira tendência de mudança nos processos de trabalho relaciona-se à difusáo dos novos métodos de organizaçáo da produçáo (para alguns autores, técnicas japonesas de organizafão da produfão, para outros, novos métodos de qualidade e produtividade), tais como just-in-time, kan-ban, entre outros. Tal difusão é relativamente independente de mudanças tecnológicas de produto ou de processo que envolvam equipamentos, matérias-primas etc. Ainda que alguns autores questionem os limites dos impactos destas técnicas sobre os processos de trabalho quando dissociados de substancial avanço na incorporação de novas tecnologias de produto e de processo (Kern \& Schumann, 1991; Berggren, 1989), parece inquestionável implicarem maior integração das funçōes de produção, controle de qualidade e organizaçăo da produção. A idéia de produzir qualidade, um dos objetivos prin- 
cipais dessas técnicas, pressupōe delegação considerável da responsabilidade sobre a qualidade para o trabalho da produção. Além disso, pressupõe também busca permanente de pequenas inovaçōcs na maneira de produzir, que nascem do conhecimento acumulado pelos trabalhadores na própria vivência da produção. Algumas dessas técnicas, como os Círculos de Controle de Qualidade, criam espaço formal para que trabalhadores de diversos níveis e funçóes participem desse tipo de processo inovativo.

A consideraçáo dessas três tendências em separado só faz sentido como abstraçáo construída para fins analíticos. Em concreto e na práti$\mathrm{ca}$, elas ocorrem em conjunto e fazem parte do mesmo processo marcado pela aceleração do progresso técnico, afetando, cada uma delas, $\mathrm{cm}$ maior ou menor grau, a maioria dos setores produtivos. Mais ainda, essas tendências reforçam-se mutuamente: por exemplo, a eliminação do trabalho manual mais pesado e repetitivo abre espaço para o melhor aproveitamento do trabalhador em atividades que requerem criatividade.

O que parece ser subjacente a todas estas mudancas no processo de trabalho capitalista é o aumento substancial da proporgão de trabalho voltado direta ou indiretamentc à inovaçăo, em todas as esferas da atividade produtiva. Também na produção, tem crescido progressivamente a proporção de tarefas e responsabilidades não rotinizáveis, de alguma forma relacionadas com objetivos que constantemente se renovam.

\section{As implicafócs para o uso do trabalho e o perfil do emprego industrial}

Nessas condiçóes, parece estar mudando radicalmente o papel atribuído ao trabalho pelas empresas, bem como a maneira de organizá-lo e administrá-lo. Em uma organização na qual o ritmo da mudança tecnológica está sendo acelerado, a habilidade da força de trabalho para rápida adaptação a novas campanbas de produçáo pode ser importante fator de competitividade. Face à intensificação da competição com base na inovaçáo tecnológica, o conhecimento acumulado pelos trabalhadores é fonte crucial de inovaçöes incrementais, que não pode ser subestimada. O acompanhamento de sistemas automatizados que estão evoluindo e sempre podem apresentar falhas inesperadas requer mão-deobra responsável, atenta e conhecedora dos equipamentos. Os benefícios da integração entre vendas, $P \& D$, e área de manufatura serão maiores se o trabalhador individual ou o grupo receberem maior responsabilidade, 
autonomia e meios para comunicar-se com outras áreas da empresia. Todos esses fatores concorrem para tornar ineficaz uma rígida abordagem taylorista, seja na organização do trabalho, seja na sua gestāo (6).

O que estamos assistindo nas economias mais avançadas é o real enfraquecimento dos dogmas tayloristas sobre a fragmentafão do trabalho, com as gerências mudando em direcão ao seu uso mais abrangente, no qual o conbecimento e a criatividade de uma forga de trabalbo responsável e cooperativa constituem contribuição bem-vinda na busca de eficiência, qualidade $\varepsilon$ inovação.

As mudanças no processo de trabalho capitalista, particularmente a maior criatividade e conhecimentos requeridos do trabalhador, refletem-se em mudanças acentuadas no padráo de uso do trabalho e nas características quantitativas e qualitativas do emprego do setor industrial das economias avançadas. Essas mudanças serão aqui sintetizadas $\mathrm{em}$ três itens (7).

Mudança na estrutura ocupacional: terceirizą̧ão e dissipaçáo do trabalho produtivo direto

A intensificaçăo das atividades de $P \& D$ e a difusão da automaçăo programável têm atuado em conjunto para acelerar a tendência - já anteriormente detectada - de queda da participação dos trabalhadores diretos na estrutura global da força de trabalho, com o correspondente crescimento do número relativo de trabalhadores indiretos (8). Tal tendência pode ser desdobrada em dois aspectos. Em primeiro lugar, aumentou substancialmente a participação, na estrutura ocupacional, de cientistas, engenheiros, técnicos e outros profissionais ligados ao suporte à gerência. Watanabe (1987), por exemplo, reporta ter decrescido de $57 \%$ para $45 \%$, entre os anos 60 e 80 , a proporção de trabalhadores da indústria automobilística japonesa engajados na produçãu, ao passo que a parcela representada pelo staff técnico e administrativo elevou-se de 19 para $34 \%$. Por um lado, essa ocorrência é reflexo do crescimento dos esforços em P\&D realizados pela indústria automobilística japonesa.

Por outro lado, como segundo aspecto, o reflexo do que Coriat (1990:199) chamou dissipação do trabalho direto de produção e extensão do trabalho indireto. São fenômenos complementares decorrentes da difusão da automação programável que, como vimos, tem efeitos significativos na eliminação do trabalho manual, sobretudo o de natureza simples e repetitiva. Ao mesmo tempo que concorre para aumentar a produtividade do trabalho direto, a introdução de sistemas automati- 
zados complexos requer maior volume de manutenção, inclusive em novas áreas de especialização, como a programação e a manutenção eletrônica de equipamentos. Pesquisas realizadas em países de industrializaçáo avançada revelam que a difusão da automação está associada à queda - na estrutura ocupacional da fábrica - da participação dos trabalhadores de produção e do correspondente crescimento dos trabalhadores indiretos (9). Finalmente, a já comentada diminuição das diferenças entre trabalho direto e indireto, bem como a maior integração de tarefas diretas e indiretas em grupos de trabalho ou novos postos de trabalho reforçam essa tendência à dissipação.

As mudanças consideradas neste tópico têm importantes implicaçóes para a estrutura ocupacional das sociedades em análise. Năo há como negar que as transformaçóes em curso na indústria e nos serviços trazem atualidade ao debate, inicialmente levantado por autores como Daniel Bell e Alain Touraine ao final dos anos 60 (10), sobre a teiceirizaf̧io das economias industriais avançadas (ou sociedades pós-industriais). Referentemente ao tema aqui tratado, o reforço da tendência à terceirizaçáo parece advir de duas mudanças. De um lado, o crescimento relativo do staff de empregados indiretos implica terceirizafão da própria indústria (entendida no sentido de terem os trabalhadores whitecollar participação crescente na estrutura ocupacional). Por outro lado, a nova onda de automação e a intensificação dos investimentos em P\&D têm sido responsáveis por crescimento substancial do setor de serviços para a produção industrial.

Novas qualificações exigidas: conhecimento, capacidade de abstraçáo e qualidades comportamentais

A questão das novas qualificações exigidas pela aceleraçăo do progresso técnico é complexa e bastante dependente dos contextos tecnológico e social. O grau de difusão da automação programável em uma indústria é variável-chave, à medida que dele dependerá maior ou menor mudança na natureza do trabalho vivo, da qual decorrerăo necessariamente determinadas tarefas. No entanto, novas tarefas podem ser agrupadas de diferentes maneiras, umas favorecendo mais o enriquecimento geral dos conteúdos dos postos de trabalho e, outras, a polarizaçáo entre trabalhos mais e menos qualificados. A escolha entre essas alternativas é, primordialmente, questão gerencial, portanto, escolha social.

Se tomarmos como objeto da nossa análise aquclas situaçōes $\mathrm{em}$ que, de alguma forma, se combinam intensificaçáo das atividades de 
P\&D e alta densidade de difusão das novas técnicas de produção, 'ć possível verificar profunda mudança nas qualificaçóes exigidas para o trabalho industrial. Apesar dos múltiplos aspectos envolvidos, essa mudança poderia ser sintetizada como perda de importancia das habilidades manuais em favor das habilidades cognitivas e comportamentais (Carvalho 1992b). Estas novas qualificaçōes poderiam ser compreendidas em três grandes grupos: conhecimento prático e tcórico; capacidade de abstração, decisão e comunicação; e qualidades relacionadas à responsabilidade, atençáo e interesse pelo trabalho.

Não é difícil entender porque a incorporação das novas tecnologias, intensivas em conhecimento científico, contribuiu para aumentar a complexidade das tarefas e dos requisitos relativos a conhecimento em áreas como $\mathrm{P} \& \mathrm{D}$, engenharia, controle de qualidade etc. No entanto, também na produçáo as exigências de conhecimento teórico e prático parecem maiores, tanto para trabalhadores diretos, como indiretos. Pelo menos é o que indicam os estudos de caso dos setorcs industriais mais investigados nos países de industrialização avançada: indústria automobilística, metal-mecânica, eletrônica e química.

Kern \& Schumann (1987) chamaram a atenção para o fato de a natureza das tarefas envolvidas na operaçáo de sistemas automatizados requerer qualificaçōes de novo tipo, baseadas no conhecimento teórico e prático do processo produtivo. Em relatório posterior, Schumann (1990) confirmou que o trabalho da categoria emergente dos Controladores de Sistemas (categoria nova e típica de sistemas produtivos automatizados), nos três setores da indústria alemã por ele pesquisados (11), exigia conhecimento teórico: "um monitoramento criterioso de processos e sistemas de máquinas muito complexos não pode ser desenvolvido sem o conhecimento dos princípios fundamentais e a necessidade de competência teórica é muito alta para um treinamento on-the-job" (Schumann, 1990:20).

Não obstante, sistemas complexos apresentam comportamentos também complexos, que muitas vezes só podem ser apreendidos através da experiência acumulada pelo trabalhador em sua convivência diária com os equipamentos (conhecimento prático). Além disso, dado o alto nível de integração dos processos produtivos automatizados, as atividades de supervisão/controle desses sistemas exigem também visōes mais integrada e abrangente do processo. Schmitz (1988), a partir de um surpeda literatura sobre a experiência britânica, e Coriat \& Zarifian (1985), baseando-se na experiência francesa, enfatizaram o aumento da importância estratégica da área de manutençăo, e a complexificaçáo das 
tarefas, em função dos novos conteúdos envolvidos (por exemplo, eletrônica) e da exigência de maior rapidez de resposta e eficácia. Pode-se ainda acrescentar que, dentro do princípio do aperfeiçoamento permanente, da busca constante de pequenas inovaçöes que nascem do conhecimento do processo produtivo real, quanto maior o conhecimento prático e teórico acumulado pelos trabalhadores, maiores serão os ganhos inovativos advindos dessa fonte.

No entanto, se as conclusões acima estão baseadas em determinados setores produtivos, ou mesmo em seçóes dos processos de produção desses setores, a cautela recomendaria evitar conclusão apressada a respeito da tendência geral ao aumento do nivel de qualificaçăo dos trabalhadores industriais diretos das economias mais avançadas. Além do fato de os estudos existentes estarem bastante concentrados em limitado número de setores, há outros motivos metodológicos para tal cautela. As mudanças introduzidas pelas empresas na organização do trabalho são, na maioria dos casos, experimentais, e a diversidade de situaçóes não parece indicar que haja um modelo dominante. Além disso, dado o material empírico das pesquisas disponíveis, em geral, não se valer de medidas objetivas do grau de qualificação, fica difícil estabelecer comparaçóes.

O que parece inquestionável é, com o avanço da automação programável, haver tendéncia para que o trabalbo direto assuma caráter de monitoramento, passando a exigir do trabalbador maior capacidade de abstrafão, decisão, comunicação e maior grau de responsabilidade. No entanto, como sugere Coriat (1990), trabalho mais abstrato não significa necessariamente trabalho mais qualificado. A literatura sobre experiências de automaçáo em economias avançadas mostra que, apesar daquelas tendências gerais, ainda permanece considerável diferenciaģão entre setores industriais, depois da incorporaçâo de novas tecnologias, com relaf̧ão ao grau de qualificação demandado dos trabalbadores de producão e quanto ao tipo de conbecimento requerido (Carvalho $1992 \mathrm{~b}$ ).

Há dois tipos de fatores - tecnológicos e sociais - influenciando essas diferenças. Os fatores tecnológicos referem-se sobretudo à natureza do produto e à complexidade do processo produtivo. Nas induistrias voltadas para produtos e processos produtivos mais complexos - como as estudadas por Kern \& Schumann - as pesquisas e estudos de caso mostram que a intensificafão da difusão da automafão programápel geralmente vem acompanbada de uma elevafão do nivel médio de qualificação da forfa de trabalbo. A natureza dos conhecimentos envolvidos, porém, depende muito do tipo de produto. Na produção metal-mecânica de pequenos lotes de produtos discretos, por exemplo, a questão crucial 
refere-se à possível integração (e ao grau dessa integração) das atividades de programação à atividade de produção. $O$ tamanho do lote influencia a racionalidade econômica dessa opçáo (Sorge et alii, 1983; OIT, 1988). Já na produçáo em série (a exemplo da indústria automobilística), a principal questáo envolvendo novos conhecimentos está relacionada à profundidade da integraçăo de tarefas de manutençăo com tarefas de produçáo. No entanto, em contraste com a experiência dessas indústrias mais complexas, há estudos de caso mostrando que a difusão da automaçăo programável em setores tradicionais como confecçōes (Hoffman \& Rush, 1984), bebidas (Davies, 1986) e biscoitos (Buchanan \& Boddy, 1983) não levou a alteraçôes significativas do grau de qualificaçáo exigida dos trabalhadores de produção, quando não levou efetivamente a determinada desqualificação.

Sobre esses condicionantes tecnológicos, agem fatores sociais que determinam diferentes opföes com relafão à organizaçăo do trabalbo (organização das tarefas em postos ou grupos de trabalho). São fatores que explicam, por exemplo, porque a experiência da indústria automobilística alemã favorece soluçōes que implicam maior integração entre tarefas de produção e manutenção, em comparação com a experiência francesa, na qual a definição das tarefas dos novos trabalhadores de produção em geral é mais pobre e, como resultado, o aumento do seu grau de qualificaçáo é também menor. Sorge et alii (1983) relataram que, além do tamanho do lote, a orientafáo da gerencia por maior controle ou por maior autonomia do trabalbo é decisiva na definifáo do nopo perfil dos trabalbadores de produfáo e, portanto, de seu grau de qualificafáo. A integração das tarefas de produçáo com as tarefas de programaçáo é, geralmente, maior na Alemanha, onde as gerências parecem mais abertas para delegar responsabilidades, do que na Grã-Bretanha, país no qual é maior a preocupação com o controle sobre o trabalho.

Para além da discussão da profundidade e da extensão dos novos conhecimentos exigidos, parece claro que os novos perfis profissionais associados ao avanço da automação e à difusão dos novos métodos de organização da produção requerem maior capacidade de abstração, exercício do discernimento, e certas qualidades comportamentais relacionadas com a confiança e a cooperação. Como lembra Coriat, "esta dissoluçáo do trabalho direto e a extensão do trabalho indireto poderiam também ser vistas como um movimento geral em direçáo à abstraçáo do trabalho', abstração significando que, mais do que o manejo concreto de ferramentas baseado em prescriçóes de operaçáo, agora estamos lidando com a capacidade para ler, interpretar e decidir com base em dados formalizados e fornecidos pelas máquinas" [grifos meus] (1990:202). Po- 
de ser ainda acrescentado que a inclusão, no escopo do trabalho de produção, de responsabilidades como controle de qualidade e busca permanente de pequenas melhoras no processo produtivo reforçam a necessidade de o trabalhador compreender a lógica e as condiçóes do seu trabalho, estabelecer relaçôes e decidir entre alternativas.

Finalmente, parece também ser exigência bastante difundida, nas novas condiçóes de produção, que a força de trabalho apresente atitude confiável, cooperativa e interessada pelo trabalho e pelos objetivos da produção. Se considerarmos as características centrais do processo de reestruturação produtiva já comentadas, e suas implicaçóes para o processo de trabalho, não é difícil compreender a origem dessas exigências. Apenas para ficarmos com as implicaçốes da difusão da automação programável, vale lembrar que, em condiçóes de produção altamente automatizada e integrada, os custos de quebras e interrupçóes são muito altos (comparativamente a processos semi-automatizados). Função não apenas dos custos de manutenção dos equipamentos, mas também dos custos geralmente maiores - pela perda de produçáo - advindos de paradas em produção integrada, tais questóes requerem dos trabalhadores responsabilidade para atuar dentro das especificaçóes, atenção para perceber rapidamente sinais de pane, e interesse (motivação) para antecipar problemas, intervir no processo em tempo adequado etc. Da mesma forma, conceitos de organização da produção como qualidade total e grupos de aperfeiçoamento pressupóem clara motivação da força de trabalho para participar, refletir criticamente sobre o trabalho e sugerir modificaçōes.

Para concluir, ainda que todas as evidências levem a crer ser possível variarem significativamente a profundidade e a extensão dos novos conbecimentos exigidos dos trabalhadores em função da incorporaçáo das novas tecnologias de produçáo, há tendência generalizada de maior exigência de raciocínio, abstração e capacidade de decisão. Aumenta também a importância da responsabilidade e da motivação no trabalho. Assim, o operário limitado, de gestos mecanizados e pouco discernimento, típico do modelo taylorista/fordista de organização da produção, deixa de ser funcional para os objetivos gerenciais dentro da nova etapa aberta com a recente aceleraçáo do progresso técnico. Como veremos, essa mudança está associada ao crescimento substancial da importância de adequada educação formal da força de trabalho.

Maior exigência de escolaridade formal

As mudanças nas exigências de qualificação tendem a afctar a estru- 
tura ocupacional também no que se refere ao grau de escolaridade formal. Nas economias industriais mais avançadas parece haver clara tendência para aumentar o grau de escolaridade da força de trabalho, dentro e fora da fábrica (OIT, 1988).

Tal crescimento está certamente relacionado ao aumento do pessoal qualificado engajado em atividades de $P \& D$ e engenharia, mas não apenas nesses setores. $\mathrm{Na}$ indústria automobilística alemã, a existência prévia de mão-de-obra com alto nível de escolaridade formal $\mathrm{e}$ treinamento vocacional facilitou a transição para o novo esquema de organizaçáo do trabalho nas plantas mais automatizadas, nas quais os novos cargos de controladores de sistemas puderam ser enriquecidos com tarefas mais complexas de manutenção (Jurgens et alii, 1986). O fato de os operários de produção alemães, em geral, terem educação básica e profissional acima da exigência média da anterior estrutura fordista contribuiu para uma transiçăo mais rápida.

Parece provável que as indústrins $\mathrm{em}$ atual estágio de automatização, sobretudo as produtoras de produtos mais complexos, seguirão o caminho das indústrias de processo em fluxo contínuo, nos quais o nível de escolaridade formal é mais elevado, em todos os níveis da mão-deobra. As novas exigências de capacidade de abstraçăo, raciocínio crítico c presteza de intervenção são de tal ordem, que o grau e a qualidade da escolaridade formal terminam por ter impacto direto sobre a produtividade do trabalho.

Neste ponto, nada melhor que o exemplo do Japáo e das novas economias industrializadas do Leste Asiático. Estas economias entenderam que o investimento na universalização de adequada educaf̧ão de primeiro e segundo graus era requisito essencial para acelerar a adofão, a adaptaf̧ão e a absorfáo de tecnologia. $O$ espetacular uso da engenharia reversa feito por países como Coréia, Taiwan, além do próprio Japão, permitindo-lhes chegar até os estágios finais na absorção de tecnologias importadas, seria impensável num contexto com mão-de-obra pouco escolarizada. O sucesso desses países, em particular nas indústrias que constituem a base do novo paradigma tecnológico, deve muito aos pesados investimentos feitos na melhora e universalizaçáo da educação secundária e na ampliação da educação superior, em particular sua ênfase em engenharia e outras áreas de ciência aplicada (Dahlman, 1989). Na tabela 2, percebe-se a dimensáo do avanço da educaçáo secundária e superior nesses países, contrastando-o com a situação de paísès da América Latina, entre eles o Brasil. 
Tabela 2

Indicadores de Educação em Países Selecionados

Percenta-

gem do

Grupo

Etário

Corćia

Taiwan

Japão

México

Brasil*

Matriculado

Ensino

Secundáro

(1965)

(1985)

35

94

38

82

17

16

996

55

$35^{*}$

Ensino

Superior

(1965)

(1985)

6

7

13

4

16

2

32

13

30

11

Estudan-

tes do En-

sino Supe-

rior como

3,6

2

2

1,5

1,1

$\%$ da

população

Estudan-

tes de

Engenharia

Total

(milhares)

Como

$\%$ da

população

\section{$227,6 \quad 128,7$}

418,9

281,8

164,6

0,54

0,68

0,34

0,35

0,13

Ano

(1987)

(1984)

(1986)

(1986)

Fonte: Dahlman e Frischtak, 1990 (apud Lall, 1990)

* Os dados relativos ao Brasil provavelmente subestimam seu indicador porque, devido a diferentes definiçóes de curso secundário, a faixa etária considerada como base no caso brasileiro vai de 15 a 17 anos, em contraste com as faixas consideradas para México e Japáo (12-17) e Coréia (10-18).

A necessidade de a força de trabalho receber adequada educação básica vem tornando obsoleto o conceito que separa esta da educação profissional. Embora a educação profissional continue necessária à for- 
mação de determinadas familias de profissionais (eletrônica, mecânica, química), base a partir da qual as novas categorias de trabalhadores da produçáo estáo se constituindo, a exigência de formaçáo no segundo grau vem a ela se agregar.

Políticas de gestão da mão-de-obra voltadas para a estabilização e o envolvimento

O desenvolvimento de novos requisitos comportamentais, educacionais e de conhecimento do processo produtivo exigidos dos trabalhadores, como decorrência da mudança tecnológica acelerada, tem levado as empresas a introduzirem inovaçóes em suas políticas de pessoal e de relaçóes industriais. Nas empresas dos países mais industrializados, é crescente o número de experiências com novas políticas de salários e carreiras, desenhadas com o intuito de desenvolver o comprometimento dos funcionários com os objetivos da organizaçáo e estabilizar o vínculo empregatício.

A partir do já exposto em tópicos anteriores, é possível entender a motivação das empresas para tal mudança. $O$ investimento em treinamento para a operação de novos equipamentos, ou desenvolvimento de funçóes dentro das novas técnicas japonesas, é geralmente elevado. As empresas têm interesse em preservar este tipo de ativo. Da mesma forma, há grande interesse em preservar as cabefas e as idéias desenvolvidas e acumuladas ao longo de anos num laboratório de pesquisa. $O$ conhecimento detalhado da produçáo, base do aperfeiçoamento permanente, exige tempo, confiança e estabilidade do vínculo empregatício. Confiança recíproca é também a base para que se possa contar com atitude responsável da parte de trabalhadores que operam equipamentos dispendiosos. Todos esses fatores convergem no sentido de ampliar o interesse das gerências pela estabilização de sua força de trabalho. Assim, parece confirmar-se a expectativa de Schmitz (1985) de que a difusão de novas tecnologias iria ampliar a tendência de as empresas buscarem a estabilizaçáo de seus empregados, tendência essa caracterizada pelo autor como típica da produçáo automatizada em fluxo contínuo (na indústria química, por exemplo).

A novidade, contudo, está nas atuais experiências em matéria de políticas de remuneraçāo e carreira implicarem mudanças mais profundas do que o simples pagamento do salário-confiança (reliability wage), identificado por Schmitz como a peça central das políticas de estabilizaçáo naquele tipo de produçăo. Os resultados encontrados por este 
autor na indústria química referiam-se à disposição da gerência em pagar salários acima da média do mercado, a fim de manter a estabilidade do emprego, necessária para a criação de confiança nas relaçóes de trabalho.

Ainda que tal aspecto não esteja descartado, nas experiências atuais predominam sistemas nos quais se busca antes vincular a progressão funcional e salarial ao desempenho individual dos trabalhadores. Sistemas de carreira/remuneração do tipo pay-for-learning ou performancepay, na trilha da experiência japonesa, desvinculam a carreira individual de postos de trabalho específicos. No caso do pay-for-learning, por exemplo, os trabalhadores são promovidos salarialmente à medida que são capazes de aprender e dominar novo grupo de qualificaçōes, que podem inclusive estar fora da produção. Assim, as carreiras são mais abertas, podendo um trabalhador de produção desenvolver competência e atuar na área de manutenção. Esse tipo de esquema de carreira está geralmente associado a fábricas bastante automatizadas (pelo menos no caso dos países ocidentais), e implica profunda re estruturação da divisăo do trabalho e do conceito de posto de trabalho. Ele ajusta-se a estruturas ocupacionais com menor número de classificaçóes e postos definidos de maneira mais abrangente (Carvalho, 1992b).

A experiência japonesa, no entanto, demonstrou que a desvinculação da carreira do posto de trabalho não depende necessariamente de alto nível de automação, nem tem como critério exclusivo a aprendizagem de novas qualificaçóes. A avaliação de desempenho japonesa, na qual as chefias detêm poder considerável, tem forte componente de lealdade e dedicação como critério. Em contrapartida, o sistema japonês oferece outras compensaçóes, como garantia de emprego (para certa parcela da força de trabalho) e promoçóes determinadas pelo tempo de serviço, que ajudam a compor o quadro de estímulos para o envolvimento dos trabalhadores com os objetivos das empresas (Humphrey, 1992).

É necessário atentar às críticas feitas a esses novos sistemas, que apontam para o enfraquecimento da capacidade de atuação coletiva dos trabalhadores. Malsch et alii (1984), por exemplo, comentam o caso japonês como verdadeira $r e$ feudalização das relaçóes de trabalho. No entanto, não há como negar que os novos esquemas de gestáo do trabalho, em suas diferentes formas, representam ruptura com os padróes tradicionais, nos quais as perspectivas de carreira e ascensão individual eram, para a grande massa de trabalhadores manuais com pouca qualificaçăo, bastante limitadas. 


\section{O contraste da situaçāo brasileira: fragilidade tecnológica, permanência do taylorismo e uso predatório do trabalho}

Com relação à experiência dos países de industrialização avançada e dos NICs asiáticos, a situação brasileira apresenta marcante contraste. Embora o processo de industrialização no Brasil também tenha ocorrido com velocidade e vigor notáveis, tem sido marcado pelo baixo dinamismo tecnológico, o que constitui fragilidade crucial no atual momento de reestruturação baseada na aceleração da mudança tecnológica.

A baixa prioridade atribuida historicamente à capacitaçāo tecnológica no Brasil, aliada aos efeitos da crise sobre o investimento, que terminaram por retardar o processo de modernizaf̧äo e a difusâo de novas tecnologias e técnicas organizacionais, são os determinantes mais diretos da relativa permanência de processos de trabalho convencionais, assentados sobre o princípio taylorista da separaçāo entre o saber e o fazer. Assim, em que pese a ocorrência de exceçóes setoriais, prevalecem no país processos de trabalho industriais com baixo grau de automação, organizados com base na fragmentação do trabalho e na constituição de postos de trabalho com tarefas simplificadas, cuja participação no processo inovativo das empresas, quando ocorre, é marginal.

Essa situação reflete-se claramente nas características estruturais da força de trabalho industrial brasileira, bem como no padrão - predatório - prevalecente no uso do trabalho. A maior parcela da força de trabalho industrial é composta de trabalhadores semi-qualificados ou não-qualificados, com baixo grau de escolarização formal e cujas experiências de treinamento săo de curta duração. Os salários da mäo-deobra industrial no Brasil estão entre os mais baixos do mundo, enquanto a taxa de rotatividade no emprego, mesmo excluindo a construção civil, está entre as mais altas. Além disso, as empresas brasileiras investem pouco em treinamento e formação, quando comparadas com padróes internacionais. Esses são sintomas de que, na maior parte das empresas, ainda prevalecem políticas de pessoal de visão curta - inexistência de carreiras, baixos salários, uso da demissáo como instrumento disciplinador e como expediente para controle de reivindicaçóes salariais -, revelando pouco interesse das gerências com a fixação da força de trabalho. Examinemos essa situação em maiores detalhes. 


\section{O escasso dinamismo tecnológico $e$ \\ o atraso relativo da induistria brasileiva}

Ainda que, dentro do marcante quadro de heterogeneidade tccnológica de nossa estrutura industrial, parcela ponderável dos setores industriais seja relativamente moderna, atualizada em termos de tecnologias de produto e processo (Araújo Jr. et alii, 1992), a indústria brasileira apresenta baixo grau de capacitação tecnológica, isto é, dificuldade estrutural em inovar. Tal dificuldade deve ser entendida no contexto de um padrão de industrializaçáo marcado pela exploração predatória de măo-de-obra barata e de recursos naturais abundantes e na manutenção de protecionismo generalizado e ilimitado no tempo (12).

É importante distinguir aqui entre atraso/modernidade tecnológica e baixo grau de capacitaçáo ou dinamismo tecnológico. Enquanto o primeiro é conceito estático e diz respeito ao grau de atualização (com relação às tecnologias mais modernas) das tecnologias de produto $\mathrm{e}$ processo utilizadas na indústria, o segundo refere-se à capacidade das firmas de acumularem conhecimento tecnológico, que lhes permita evoluir em cadeia, desde a compra e a utilização competentes de pacotes tecnológicos, até à capacidade de geração endógena de inovaçóes. Trata-se, portanto, de conceito dinâmico, de particular importância para países de industrializaçáo recente, nos quais o dinamismo tecnológico é, em parte, funçáo da capacidade das firmas de "completarem o ciclo de assimilação de tecnologias importadas" (Enos \& Park, 1988) (13).

Se efetivamente há modernidade em áreas do parque industrial brasileiro, essa ocorrência é devida, sobretudo, a setores como petroquímica, papel e celulose, parte do setor siderúrgico, entre outros, serem de constituição relativamente recente e terem sido implantados com base em importaçáo de pacotes tecnológicos atualizados. No entanto, é preciso enfatizar que, de acordo com os resultados de pesquisas recentes (Furtado et alii, 1992; Coutinho \& Suzigan, 1992), a indústria brasileira apresenta, de maneira geral, baixo grau de capacitação tecnológica, o qual tem se refletido em incapacidade para gerar ganhos significativos de produtividade e desenvolver inovaçōes e aperfeiçoamentos em seus produtos.

Tal afirmação deve ser qualificada dentro do contexto de heterogeneidade da indústria brasileira. Nas empresas mais atrasadas, a fragilidade tecnológica manifesta-se até mesmo na sua dificuldade em identificar oportunidades tecnológicas, escolher equipamentos e fornecedores de tecnologias e utilizá-los adequadamente. Mesmo nos setores mais 
atualizados tecnologicamente (como na siderurgia c na petroquímica, entre outros), ainda que se tenha desenvolvido considerávcl capacitação operacional nas empresas líderes, propiciando nível eficiente de operação e introdução de pequenos aperfeiçoamentos tecnológicos, houve pouco progresso em direção a estágios mais avançados de capacitação tecnológica. Em que pesem as exceçōes já conhecidas, as empresas desses setores pouco fizeram no sentido da assimilagão efetiva das tecnologias importadas, que lhes permitisse não apenas reproduzir produtos e processos industriais, mas neles introduzir modificaçōes significativas c, principalmente, desenvolver produtos e processos inéditos (14).

A assimilação de tecnologias e o desenvolvimento endógeno de inovaçōes são processos cumulativos, que exigcm das empresas significativa mobilização de recursos - financeiros e humanos - e, năo menos, organização e estratégia de longo prazo voltadas para estes objetivos. Um bom indicador da fragilidade das empresas brasileiras, neste aspecto, é a reduzida dimensão de seus investimentos em $P \& D$. Como observado na tabela 1 , tais investimentos podem ser considerados desprezíveis em qualquer comparação internacional $(0,05 \%$ do PIB no Brasil, contra $1,3 \%$ na Coréia, $1,77 \%$ nos EUA, $2,79 \%$ no Japão, e $0,59 \%$ na Itália - a menor taxa entre os países industrializados). Mais ainda, o grau de concentração dos gastos das empresas industriais brasileiras em P\&D reforça a idéia de ilhas de capacitação tecnológica (em sua maior parte estatais) num mar de baixo dinamismo. De acordo com recente estudo do Banco Mundial (Dahlman \& Frischtak, 1990), dentro do universo reduzido das empresas industriais que conduzem atividades de $\mathrm{P} \& \mathrm{D}$ formalizadas como tal $(0,7 \%$ das empresas industriais do setor formal no Brasil), as do setor produtivo estatal (cerca de 50) eram responsáveis por $62 \%$ dos dispêndios com $P \& D$, enquanto que um seleto grupo de 25 empresas privadas era responsável por 17,4\% (15). Em outras palavras, menos de 100 empresas brasileiras, em sua maior parte estatais, eram responsáveis por $80 \%$ do investimento realizado em desenvolvimento e capacitação tecnológica.

Esta fragilidade tecnológica da induistria brasileira, herança estrutural da forma assumida pelo processo de industrializaçáo por substituição de importaçóes no Brasil, parece difícil de ser revertida na presente conjuntura. A intensificação de atividades de $\mathrm{P} \& \mathrm{D}$ e capacitaçáo tecnológica das empresas exigiria um esforço de investimento incompatível com o atual contexto econômico e institucional. No atual quadro de incertezas econômicas e de dificuldades que o Brasil vem encontrando para estabilizar sua economia e recuperar a capacidade do Estado de articular políticas, as decisóes de investimento são conservadoras e 
defensivas. Não cabe aqui aprofundar a discussño, mas vale registrar que a substancial queda da taxa de investimento na década de 90 (agravada nos últimos dois anos) reflete a prevalência de estratégias de modernização defensivas, destacando-se objetivos como racionalização, redução de custos, enxuggamento, mais do que mudanças de maior fôlego nas estratégias tecnológicas (16).

Tais estratégias defensivas refletem-se claramente na lenta difusão da automaçăo flexível na indústria brasileira. Com maior intensidade entre os usuários da automaçáo da manufatura do que entre as indústrias de processo, acumula-se enorme defasagem entre a indústria brasileira, de um lado, e os países de industrializaçáo mais avançada e os tigres asiáticos, de outro.

Para ilustrar esse ponto, vale recorrer à atualização e à adaptaçáo realizadas pelo ator deste texto, do indicador de intensidade de uso de equipamentos de automação de base microeletrônica desenvolvido por Edquist \& Jacobsson (17). O exercício revelou impressionante defasagem do Brasil com relaçáo à Coréia. Para dados de 1987, as densidades coreanas eram de 5.176 para máquinas-ferramenta com controle computadorizado (MFCN), 1.060 para robôs industriais, e 1.437 para sistemas $\mathrm{CAD}$; enquanto as densidades brasileiras eram respectivamente de 2.298 (MFCN), 52 (robôs) e 422 (sistemas CAD). A defasagem ć gritante na difusão de sistemas de robótica. Em 1987, a Coréia já havia incorporado mais de 500 robôs à produçáo industrial, a maior parte deles na indústria automobilística (OIT, 1988), em contraste com os 87 até então introduzidos no Brasil. Desde então, a defasagem ampliou-se, em funçáo da estagnação de investimentos no Brasil.

Entende-se essa defasagem quantitativa quando se examina a natureza dos investimentos em automaçáo industrial no Brasil. Conforme assinalado em diversos estudos setoriais, o objetivo conservador ou defensivo da maior parte desses investimentos revela-se, em graus variáveis, no caráter seletivo e pontual da incorporaçáo dessas inovaçóes (18). Tratando-se, na maior parte dos casos, de processos de renovaçăo de capacidade produtiva já existente, as estratégias de automação concentraram-se em partes do processo produtivo ou mesmo em postos de trabalho e funções singulares considerados estratégicos para ganhos de qualidade. Embora tais estratégias possam ter se revelado adequadas para enfrentar situaçáo de crise, um de seus resultados é que poúco se avançou no país em termos de conhecimento da implementação de sistemas complexos e integrados de automação da manufatura, em contraste com a situaçáo da Coréia e mesmo do México. 
Outro aspecto fundamental da difusão das novas tecnologias de produção no Brasil referc-se à relativa ausência de sinergia na incorporação da nova base técnica. A fragilidade tecnológica dos usuários das novas tecnologias de automação e controle de processos industriais terminou por cobrar seu preço em termos de inadequação ou subutilização dessas tecnologias. Razoável grau de acumulação de conhecimento tecnológico de produto e processo anteriormente à mudança para a base microeletrônica parece ser fator essencial para que as empresas possam tirar o máximo do potencial oferecido pela nova base (Carvalho 1992a).

Os mesmos fatores que retardam a difusão de novos equipamentos de produção atuam no sentido de atrasar a incorporaçāo de novos métodos (japoneses) de organização da produçáo voltados para o aumento da qualidade e produtividade. Nesta área, a identificaçăo da difusão é mais nebulosa, à medida que as inovaçóes organizacionais são menos tangíveis (que um equipamento, por exemplo), tornando difícil separar o discurso empresarial da verdadeira prática. As evidências têm de basear-se em trabalhosos estudos de caso, com discutível validade quanto à coleta de dados e estatísticas sobre modificaçóes organizacionais.

Há muito discurso e debate, nos meios empresariais e governamentais, sobre a necessidade de as empresas brasileiras adotarem novos métodos de qualidade e produtividade. $O$ governo Collor chegou a iniciar implementaçáo de programa formal com esse objetivo, considerado um dos esteios de sua política industrial. Proliferam artigos de consultores, seminários, entrevistas de empresários e gerentes sobre $o$ assunto.

O grau de difusão e a natureza das mudanças organizacionais introduzidas no Brasil, no entanto, parecem estar aquém da propaganda. Criteriosa pesquisa encomendada recentemente pelo IPEA, com patrocínio do Banco Mundial (Fleury \& Humphrey, 1992), concentrou-se numa amostra de empresas que estavam introduzindo novos métodos e técnicas (TQC, JIT, TPM etc.) e levou às seguintes conclusões:

- existe, efetivamente, reduzido número de empresas no Brasil que estão avançadas na introdução dos novos métodos de Q\&P;

- a imensa maioria das empresas industriais sequer iniciou esforços nessa direção;

- o ritmo de difusáo é lento e tem sido sujeito a retrocessos.

O mais importante, no entanto, é que a introduçăo desses métodos no Brasil passa por adaptação, tendendo a evitar mudanças mais 
profundas na organização do trabalho, e concentrando-se nos aspectos mais formais e técnicos dos novos métodos (Posthuma, 1990; Humphrey, 1991). Fleury \& Humphrey (1992) chamam a atenção para o fator que poderia ser identificado como o principal obstáculo à difusão dos novos métodos de qualidade e produtividade: "a amplitude e a profundidade das mudanças exigidas por tais programas" . Em condiçóes de retração do investimento, eu acrescentaria, é pouco factível (embora não impossível) esperar mudanças em profundidade, ponto que será retomado adiante.

\section{A Permanência de processos de trabalho convencionais: o pequeno conteuido inovativo do trabalho no Brasil}

A fragilidade tecnológica da indústria brasileira e sua defasagem na incorporação de novos conceitos e técnicas de produçáo estáo na raiz do grau relativamente modesto, em comparação com outras economias, das mudanças por que têm passado os processos de trabalho industriais no Brasil. Para facilitar a argumentação, faço a seguir uma comparação sistemática com as principais tendências levantadas no tópico referente às implicaçóes da aceleração capitalista.

Pequena participaçăo das atividades de inovaçăo a agregação de valor

Se a tendência nas economias mais avançadas é para crescente integração entre as funçóes de inovação e produçáo, com a agregaçáo de valor cada vez mais se fazendo a partir de atividades voltadas à inovação em todos os níveis da empresa, na produfäo industrial brasileira prevalece baixa participafão das atividades de inovagão na agregafão de valor e a dissociaģão entre inovafão e produção.

A baixa participação de atividades de inovação no valor agregado pela indústria é reflexo de sua baixa capacitação tecnológica, a qual, por sua vez, condicionada pela escassez de investimentos em P\&D. A pequena expressão da formalização das atividades de $P \& D$ nas empresas brasileiras reflete-se, por exemplo, na presença quase insignificante de pesquisadores em seus quadros. De acordo com Dahlman \& Frischtak (1990:5), apenas $2 \%$ do universo de pesquisadores empregados no país em 1987 (totalizando pouco mais de 1.000 pessoas) faziam parte dos quadros das empresas, sendo que mais de dois terços deles exerciam suas atividades em empresas do setor público (18). Mesmo em setores industriais com maior índice de formalização de atividades de $P \& D$, como 
na petroquímica, a importância dessas atividades, medida no númcro de patentes registradas ou de pesquisadores empregados, é extremamentc pequena, quando comparada com padróes internacionais.

Da mesma maneira, a preocupação com a inovação ainda é rcalidade distante do chão-de-fábrica. Nesse sentido, minha investigaçáo no setor petroquímico brasileiro foi bastante reveladora (Carvalho 1992b). Embora o conhecimento prático sobre processos acumulado pelos opcradores petroquímicos seja potencialmente decisivo para a capacitação tecnológica dessa indústria, já que na maioria dos casos ela opera com pacotes tecnológicos importados pouco transparentes para os engenheiros, as práticas de organizaçáo do trabalho adotadas pela maioria das empresas petroquímicas brasileiras não facilitam o desenvolvimento c aproveitamento desse conhecimento. Ao contrário das práticas de trabalho em equipe com rodízio de tarefas, comuns nas plantas de processo contínuo em países mais industrializados, as empresas petroquímicas brasileiras mantêm fórmula ultrapassada que divide e separa tarefas de controle central das tarefas de campo (operadores de painel $\mathrm{x}$ operadores de campo) e fixa os operadores em áreas específicas da fábrica por longos períodos. Isto dificulta o desenvolvimento da visão mais integrada pelos operadores, a qual poderia constituir excelente fonte de informáçóes e conhecimento para o setor de engenharia.

\section{A permanência de processos intensivos em trabalho manual}

Ao contrário da tendência encontrada nas economias mais industrializadas, em que o avanço da automação programável implicou significativo deslocamento do trabalho manual direto (sobretudo das tarefas manuais mais simples), o caráter seletivo da difusão dessa nova tecnologia nas fábricas brasileiras não resultou em qualquer mudança significativa na natureza do trabalho nos processos mais intensivos em máode-obra. Enquanto nos sistemas mais automatizados há a emergência dos Controladores de Sistemas, cujas tarefas aproximam-se, pelo menos nos objetivos, das de manutençáo, nas fábricas brasileiras semi-automatizadas as tarefas de produçáo, em sua maioria, continuam a ser substancialmente diferentes daquelas de manutenção e controle de qualidade.

Nesse sentido, o caso das indústria de montagem, em particular do setor automobilístico, é paradigmático. A automação seletiva deixout para o trabalho humano o grosso das operaçōes de manufatura, incluindo tarefas menos nobres de montagem. Dado o quadro de instabilidade econômica e.retraçáo de investimentos em novas fábricas mais automa- 
tizadas, fatơres como o baixo custo da mão-de-obra não-qualificada e o custo que representaria o treinamento ou a substituiçăo de colctivos de trabalhadores pouco qualificados parecem ser determinantes da continuidade de práticas tradicionais de organização do trabalho. É difícil conceber como um esquema de organização do trabalho que não estivesse fundamentado na continuidade de postos de trabalho simples $\mathrm{c}$ fragmentados poderia ser economicamente eficiente. $O$ baixo nível de automação em indústrias de produçăo em massa termina por induzir a continuidade da fragmentaçáo do trabalho, particularmente quando se trata da modernização de plantas já existentes, nas quais a máo-de-obra é barata (Carvalho 1992b).

\section{A permanência de princípios tayloristas/fordistas de organização do trabalho: a continuidade da divisão do trabalho}

No quadro da incipiente difusão dos novos métodos de qualidade e produtividade na indústria brasileira, os resultados das pesquisas disponiveis sugerem que as modificações introduzidas nos esquemas de organização do trabalho são superficiais, năo tendo alterado substancialmente os princípios tayloristas que determinam a estreita divisão do trabalho entre planejamento, controle e produçăo e entre as várias funções da produção (em particular a divisão entre produção e manutenção). Predominam os postos de trabalho simplificados e é apenas marginal o envolvimento dos trabalhadores com atividades de aperfeiçoamento permanente.

Mais uma vez, o caso do setor automobilístico parece servir como modelo. Em contraste com as experiências recentes em países como Alemanha e México, as gerências das montadoras brasileiras escolheram evitar qualquer mudança substancial na enraizada divisão de trabalho fordista. Ao contrário, revelando que o controle sobre o trabalho continua sendo um de seus objetivos, essas gerências aproveitaram-se das novas tecnologias para estender a organização fordista do trabalho a novas áreas de produção. Em linha com essa mentalidade no desenho dos lay-outs de produção, o desenho dos postos de trabalho continuou seguindo uma abordagem estreita. Trabalhos semi-qualificados continuam a predominar $e$ a ser definidos com base em tarefas fragmentadas e simples, especializadas por áreas de produção. Os períodos de treinamento (on-the-job) para a massa de trabalhadores semi-qualificados é curto (duração máxima de 6 meses). O número de categorias de trabalho aumentou (na contramão da tendência universal de redução do 
número de categorias). Montadores, soldadores, pintores, operadores de prensa, operadores de máquinas continuam presos aos seus postos e tarefas (Carvalho 1992b).

O que estou afirmando não significa desconhecer a ocorrência de mudanças, mas apontar para sua superficialidade. Por exemplo, embora tenham sido introduzidas tarefas de controle estatístico de processo para trabalhadores da produção $\mathrm{em}$ algumas montadoras, a responsabilidade sobre a qualidade continua fundamentalmente em área separada, de inspetores de qualidade. Nem mesmo a experiência de rotação dos trabalhadores entre diferentes especialidades semi-qualificadas tem sido tentada (Carvalho 1992b) (19).

Esse tipo de resultado, referente a estudo enfocando as relaçócs entre a automaçáo programável e a organização e uso do trabalho numa indústria de produçáo em série, é corroborado por outras pesquisas que enfocaram a difusão das técnicas japonesas de organização da produção no Brasil. Posthuma (1990:2 e 11), ao examinar as implicaçốcs dessas técnicas para a indústria de autopeças brasileira, insiste em que elas têm passado por processo de adaptaçáo ou brasilianizaf̧áo e, embora resultem em ganhos significativos de qualidade, não implicam mudanças significativas no processo de trabalho em si mesmo.

Humphrey (1991), avaliando casos de firmas brasileiras adotantes de técnicas como SPC, produção em células, Kan-ban etc., indica que, de fato, nesses casos tem havido certa transferência de funçóes de controle de qualidade para os trabalhadores nas linhas de produção, os quais também, muitas vezes, passam a operar mais de uma máquina. Todavia, o autor chama a atençáo para o fato de ser mínima a mudança na natureza do trabalho e das qualificaçóes, em muitos casos (p.14). Mais ainda, identifica certa tecnificaf̧ão na abordagem feita pelas gerências brasileiras, no sentido de muitas firmas preocuparem-se mais com o aspecto formal da adoçáo da técnica do que com a criação de condiçóes para maior envolvimento e participação dos trabalhadores. Nesse sentido, cle antevê como possível opção com baixo envolvimento, embora se possa questionar os limites de tal opçáo com relação a um dos objetivos centrais das novas técnicas, que é o da inovação permanente.

Resumindo $o$ argumento desenvolvido neste tópico, a incorporaçáo de conteúdos inovativos no trabalho industrial no Brasil tem sido marginal, se comparada às tendências dominantes nos países de industrialização avançada, 
O perfil do trabalho no Brasil:

o uso predatório de uma forga de

trabalho pouco qualificada

Sempre lembrando os limites da possibilidade de generalização sobre uma estrutura industrial heterogênea como a brasileira, passemos a examinar as implicaçóes das tendências apontadas anteriormente fragilidade e defasagem tecnológica, continuidade de padróes tayloristas de organizaçáo do trabalho e, portanto, baixo conteúdo inovativo do trabalho - para o uso da força de trabalho industrial no Brasil.

Estrutura ocupacional: uma força de trabalho pouco qualificada

O perfil ocupacional do emprego industrial no Brasil revela claramente os efeitos de atividade industrial marcada por baixo grau de inovação e predominância dos princípios tayloristas na organização da produção. $\mathrm{O}$ contraste com as tendências recentemente reveladas nos países avançados - terceirização, queda da participaçáo dos trabalhadores blue-collar, queda da participação dos trabalhadores diretos - é significativo.

No Brasil, a estrutura ocupacional da indústria é bastante polarizada: o emprego industrial parece ser majoritariamente composto por trabalhadores com pouca qualificação, participação de camada bem menor de operários qualificados e outra camada, ainda menor, composta por técnicos, engenheiros e administradores. Como pode ser observado na tabela 3 , a participação dos operários de todos os tipos no emprego da indústria de transformação é largamente majoritária (perto de $70 \%$ ), enquanto o componente de engenheiros, técnicos e profissionais de todos os tipos é de apenas $5 \%$.

O exame da composição do emprego no setor automobilístico ć mais revelador, não apenas por estarem os dados mais desagregados, mas principalmente porque permite o contraste numa indústria moderna cujo rápido e profundo processo de mudança, a nível global, tem sido bastante estudado. Em 1986, mais da metade do emprego (55\%) naquele setor correspondia a operários semi-qualificados e não-qualificados. A segunda maior categoria, com participação bem menor (15\%), é composta de operários qualificados. Finalmente, enquanto a participação dos técnicos está acima da média para a indústria de transformação, a presença dos engenheiros é desprezível $(0,7 \%)$. Em que pese o fato de 
Composição da Força de Trabalho na Indústria de Transformação Brasileira (por categoria de qualificação, em \%)

\begin{tabular}{|c|c|c|c|}
\hline Categoria & $\begin{array}{c}\text { Indústria } \\
\text { Transformação } \\
(1983)\end{array}$ & $\begin{array}{c}\text { Setor } \\
\text { Automobilístio } \\
(1986)^{*}\end{array}$ & $\begin{array}{c}\text { Setor } \\
\text { Petroquímico } \\
\text { (1986) }\end{array}$ \\
\hline $\begin{array}{l}\text { Engenheiros, } \\
\text { Técnicos e ou- } \\
\text { tros profissionais }\end{array}$ & 5,0 & $8,3^{* *}$ & 18,4 \\
\hline Gerência & 1,2 & 0,7 & 2,3 \\
\hline $\begin{array}{l}\text { Staff } \\
\text { Administrativo }\end{array}$ & 13,8 & 6,8 & 21,1 \\
\hline $\begin{array}{l}\text { Operários } \\
\text { - Supervisores } \\
\text { - Qualificados } \\
\text { - Semi-Quali- } \\
\text { ficados } \\
\text { - Não-quali- } \\
\text { ficados }\end{array}$ & 68,1 & $\begin{array}{r}75,4 \\
4,4 \\
14,9 \\
\\
47,6 \\
8,5\end{array}$ & $\begin{array}{r}48,3 \\
3,2 \\
28,2 \\
\\
8,5 \\
8,5\end{array}$ \\
\hline Serviços gerais & 3,5 & 2,9 & 5,4 \\
\hline Resíduo & 8,4 & 5,9 & 4,5 \\
\hline
\end{tabular}

Fonte: RAIS/MTb (tabulação preparada pelo autor para os setores automobilístico e petroquínico)

* Os dados referem-se às quatro maiores montadoras de automóveis instaladas no Brasil.

* Desta porcentagem, $0,7 \%$ são engenheiros e $6,7 \%$ técnicos, os quais na grande maioria sĩo desenhistas e cronometristas

ser um setor internacionalizado e, portanto, com o grosso de suas atividades de P\&D fora do país, este é um número surpreendentemente baixo para uma indústria considerada como líder do ponto de vista tecnológico ou, pelo menos, indutora de inovaçôes no complexo metal-mecânico.

Poder-se-ia argumentar que dados de um único ano não revelam tendência. Mas em outro trabalho (Carvalho \& Schmitz, 1990), o exame da estrutura ocupacional do setor automobilístico mostrou ausência de qualquer mudança significativa. Entre 1980 e 1986, período em que ocorreu o volume mais expressivo de investimentos em modernização, a participação do trabalho semi-qualificado foi ampliada. De lá para cá, o ritmo de inovaçóes no setor desacelerou-se. 
Na tabela 3 é apresentada ainda a composição do emprego no setor petroquímico brasileiro, a qual foi incluída a fim de contrastar com as anteriores e exemplificar a heterogeneidade de situaçóes, já que tal indústria apresenta força de trabalho com alto grau de qualificação. Neste caso, a participação dos operários não chega a $50 \%$, e a maioria deles é qualificada (fato decorrente de ser uma indústria altamente automatizada, operando processos razoavelmente complexos). $O$ componente qualificado da mão-de-obra na indústria petroquímica (engenheiros, técnicos, profissionais, gerentes e operários qualificados) compreende mais da metade do emprego. Apesar de as atividades de P\&D serem limitadas, a participação de engenheiros é significativa em função do interesse das empresas por sua capacitaçáo operacional. Todavia, no universo industrial brasileiro, a situação do setor petroquímico é certamente exceção, náo a regra. São pouquíssimos os setores que acompanhariam o mesmo perfil.

Baixo grau de escolaridade formal da força de trabalho

As características de escolaridade da força de trabalho industrial no Brasil são simétricas às da estrutura ocupacional polarizada já apresentada. A composição do emprego por grau de instrução indicada na tabela 4 revela a existência de massa majoritária de trabalhadores que não chegaram a completar o primeiro grau do ciclo básico (8 séries), ao lado de grupo bem menor dos que têm o segundo grau completo (11 séries) e, ainda mais reduzido, grupo de empregados com educação superior.

A indústria de transformação apresenta, de forma significativa, indicadores inferiores àqueles que se referem à economia como um todo (setor formal): a proporçáo dos trabalhadores com o primeiro grau incompleto chega a quase $70 \%$ na indústria de transformação, enquanto tal proporçáo é próxima de $50 \%$ quando considerados todos os setores de atividade. O setor automobilístico acompanha de perto a indústria de transformação. À medida que subimos para os graus superiores, $o$ desempenho da indústria automobilística é inferior ao da indústria de transformaçáo. Apenas $\mathbf{9 , 5 \%}$ dos trabalhadores automobilísticos apresentam nível de escolaridade igual ou superior ao segundo grau completo, enquanto que a proporçáo equivalente é de $13 \%$ na indústria de transformação e $28 \%$ para o setor formal da economia como um todo. Dever-se-ia considerar que os números da tabela 4 superestimam o nível de escolaridade da populaçáo trabalhadora, à medida que os dados da RAIS são obtidos apenas junto aò setor formal da economia. 
Grau de Instrução da Força de Trabalho (Brasil e Indústria de Transformação - 1985 , em \% do emprego)

\begin{tabular}{|c|c|c|c|}
\hline Grau (em séries) & Brasil & $\begin{array}{c}\text { Indústria } \\
\text { Transformaçāo }\end{array}$ & $\begin{array}{c}\text { Indústria* } \\
\text { Automobilística }\end{array}$ \\
\hline Até $4^{\mathrm{a}}$ completa & 38,0 & 49,7 & - \\
\hline $\begin{array}{l}\text { Até } 8^{\text {a }} \\
\text { incompleta }\end{array}$ & 51,5 & 68,9 & 69,3 \\
\hline $\begin{array}{l}\text { Até } 8^{\mathbf{a}} \\
\text { completa }\end{array}$ & 63,7 & 80,3 & -. \\
\hline $\begin{array}{l}\text { Até } 2 \% \text { grau } \\
\text { incompleto }\end{array}$ & 70,8 & 86,4 & 91,1 \\
\hline $\begin{array}{l}2 \% \text { grau } \\
\text { completo }\end{array}$ & 15,4 & 7,4 & 5,5 \\
\hline Superior** & 12,7 & 5,7 & 4,0 \\
\hline Total & 100 & 100 & 100 \\
\hline
\end{tabular}

Fonte: RAIS/MTB (tabulação do autor para o setor automobilístico)

* dados de 1986

* completo + incompleto

Esses números, além de serem bastante expressivos, contêm uma série de implicaçóes. Em primeiro lugar, destaca-se o contraste existente com países como Japáo, Coréia e Alemanha, que praticamente lograram universalizar o ensino de segundo grau.

Em segundo lugar, é preciso enfatizar que tal situação de escolaridade do estoque de trabalhadores industriais é produto, entre outros fatores, de uma demanda que vem sendo informada, ao longo do tempo, por critérios tayloristas de recrutamento. Em grande parte das atividades industriais, as exigências de escolaridade para a obtenção de emprego são bastante baixas, o que é compreensível quando se trata de recrutamento para empregos semi-qualificados (como visto, a imensa maioria) não exigindo mais de seis meses de treinamento. É verdade que número crescente de empresas aumentou as exigências de escolaridade nos últimos anos (21). Mas tal mudança não parece ter atingido nível crítico que levasse a mudanças significativas nos indicadores mais agre- 
gados. Minha pesquisa nas montadoras do sctor automobilístico (Carvalho, 1992b), por exemplo, revelou pouca ou nenhuma modificação nos níveis de escolaridade da mão-de-obra entre 1980 e 1986.

De qualquer maneira, e em terceiro lugar, os dados parecem indicar que, até aqui, num contexto de fragilidade tecnológica, baixo grau de inovaçăo e de difusáo de novas tecnologias, o nível de escolaridade dos trabalhadores buscado por empresas no mercado de trabalho tem sido, grosso modo, compatível com a oferta do sistema educacional, a qual, como sabemos, é também bastante polarizada. Afinal, se apenas $30 \%$ da populaçáo do grupo etário correspondente eram capazes de concluir a 8.a série do primeiro grau em 1985 (de acordo com os dados do modelo Profluxo aplicado à PNAD) (IPEA, 1991), igualmente apenas $31 \%$ da população empregada na indústria de transformaçăo possuíam tal nível de instruçăo.

Empresas e empresários têm apontado o baixo grau de instrução da mão-de-obra no Brasil como sério obstáculo à implementação de novas técnicas de qualidade e produtividade. (Posthuma, 1990; Humphrey, 1991; Gazeta Mercantil, 1991). No entanto, há evidências de que o problema, além de ser decorrência da precária oferta do sistema educacional, foi gerado pela própria indústria, insistindo em práticas de recrutamento sem privilegiar o grau de instrução, resultando a constituição de estoque de mão-de-obra de baixo grau de instrução. Desse ponto de vista, parece lógico que, caso se privilegie a estabilidade do vínculo empregatício, os esforços das empresas nesse campo devem ser prioritariamente dedicados a elevar o grau de instruçáo de seus empregados. Năo obstante, de acordo com pesquisa recente de uma grande empresa de consultoria (Gazeta Mercantil, 27/07/92:7), as maiores empresas brasileiras dedicam menos de $5 \%$ de seu investimento ao desenvolvimento de recursos humanos (atividades de treinamento), considerado, pelo mesmo estudo como absolutamente insuficiente.

Baixos salários e alta rotatividade:

o uso predatório dos recursos humanos

O quadro examinado completa-se ao acrescentarmos as práticas de gestão do trabalho que são dominantes na indústria brasileira. A revalorizaçáo do papel do trabalho nas economias mais avançadas terminou por acelerar a tendência à difusão de práticas de emprego voltadas para a estabilizaçăo do vínculo empregatício. Além de políticas salariais inovadoras, fomentadoras da identificaçáo do empregado com a empresa $e$ 
premiadoras do esforço individual, as empresas aperfeiçoaram outros esquemas visando à reduçáo de absenteísmo e rotatividade da mão-deobra.

Neste sentido, o contraste com as práticas brasileiras é, mais uma vez, marcante. É sabido que a indústria brasileira paga um dos mais baixos salários do mundo (o salário médio do setor formal da indústria de transformação equivalia a 4 salários mínimos em 1985). Mais importante, no entanto, é o fato de serem raríssimos os casos de empresas que alteraram suas políticas salariais com a perspectiva de estabilizar a mão-de-obra (à exceção de setores que, desde sua constituição, sempre dependeram grandemente da estabilidade dos trabalhadores como, por exemplo, a petroquímica e a siderurgia).

Além disso, a falta de perspectiva de carreira e o enfoque excessivamente disciplinador na relação gerência/trabalhadores continuam contribuindo para a manutençăo de taxas elevadíssimas de rotatividade. Em algumas empresas, o uso disciplinar da demissão ainda é visto como instrumento corriqueiro para resolver problemas como absenteísmo, alcoolismo, acidentes de trabalho e doenças profissionais. É o caso, por exemplo, de uma das grandes montadoras visitadas durante minha pesquisa (Carvalho, 1992b).

A rotatividade da mão-de-obra na indústria de transformaçăo havia caído em meados dos anos 80 , comparativamente aos últimos anos da década de 70, seja como decorrência da crise (que diminuiu a mobilidade dos trabalhadores), seja como efeito de maior poder de controle do movimento sindical sobre demissóes abusivas. No entanto, os números apresentados na tabela 5 evidenciam que a rotatividade de mão-deobra não apenas se mantinha muito elevada para padróes internacionais, como voltou a subir significativamente em 1988. Isto parece confirmar a continuidade de práticas de emprego que buscam a instabilização da máo-de-obra.

Pesquisas recentes (Humphrey, 1991; Gitahy \& Rabelo, 1991) apontaram casos de empresas que têm implementado tentativas dc estabilizaçáo dos trabalhadores, com isso reduzindo sua rotatividade de maneira expressiva, em associação com a adoção de técnicas japonesas de organização da produção. A estabilidade é considerada imprescindível para a criaçáo de ambiente cooperativo e de confiança na relação com os trabalhadores, e para sua colaboração com estratégias de melhoria de qualidade.

De forma análoga, já se apontara queda da rotatividade do trabalho na indústria automobilística na primeira metade dos anos 80 (Car- 
Indices de Rotatividade do Trabalho para Categorias Selecionadas na Indústria de Transformação (1985 e 1988) (em porcentagem do emprego médio anual)

Categoria

Indústria de

Transformação

Operários (grupos

7/8/9 da CBO)

Mestres

Operadores de Torno

Mecânicos

Soldadores

Trabalhadores

não-qualificados
1985

1988

42,6

53,1

59,3

72,2

31,5

36,9

37,5

41,9

33,0

38,3

55,8

64,8

71,5

Fonte: RAIS/MTb

valho, 1987; Silva, 1988), como induzida por aspectos ligados à responsabilidade requerida no trabalho com equipamentos automatizados (a despeito dessa queda, a taxa de rotatividade neste setor voltou a dobrar entre 1983 e 1986). Esses parecem ser ventos promissores de mudança de algumas das práticas empregatícias tradicionalmente adotadas na indústria brasileira. Mas nada indica que tal mudança esteja perto de constituir-se como regra.

\section{Conclusões}

Neste artigo procurou-se evidenciar que o gap a nos separar do primeiro mundo é sistemático (reproduzindo-se em todos os indicadores), tanto no referente à capacidade de inovaçáo da indústria como na maneira de perceber e lidar com o trabalho produtivo. 
A meu ver, talvez a conclusão mais importante a ser daí extraída é que nosso atraso relativamente ao perfil da força de trabalho industrial e ao uso que dela se faz no Brasil não pode ser dissociado da própria fragilidade tecnológica da indústria brasileira. São fenômenos gêmeos, originários de anos de prática de uma industrialização que: privilegiou a ocupaçáo do mercado interno, mas negligenciou a eficiência; valeu-se de protecionismo e subsídios sem limites, mas não se colocou o desafio da ocupação estruturada dos mercados externos; preferiu valer-se da exploração da mão-de-obra barata e descartável, e de recursos naturais abundantes, a construir capacitação tecnológica estruturada sobre recursos humanos e organizaçōes qualificadas, os quais permitiriam dar significativo salto qualitativo em face dos desafios apresentados pela presente fase de mudanças acentuadas na economia mundial.

Como lados de uma mesma moeda, acredito que ambos os problemas somente poderão ser resolvidos em conjunto. A questão crucial, a meu ver, diz respeito às estratégias empresariais que serão forjadas para enfrentar a crise e a competiçăo nos próximos anos. É a busca da modernização, da capacitação e da inovação que colocará para as cmpresas a necessidade de fazer uma revoluçăo em suas políticas de recursos humanos. Somente quando parcela substancial das empresas brasileiras adotarem estratégias buscando a acumulaçáo do conhecimento tecnológico, os processos de trabalho seráo efetivamente modificados e a demanda por trabalho qualificado no Brasil assumirá grandes proporçốes.

Mas não será o mercado - mesmo sendo mais competitivo - que por si próprio criará condiçóes para uma mudança de tal envergadura nas estratégias empresariais. Tal mudança exige a recriação de ambiente favorável ao investimento, em particular do investimento em desenvolvimento tecnológico. $\mathrm{E}$ isso exige muito mais do que a liberação das forças de mercado. Cabe à política econômica e, em particular, à política industrial e tecnológica fazê-lo. Certamente tal procedimento tem relação com a estabilizaçáo da economia e a recuperação da confiança no futuro, mas refere-se também a mecanismos de financiamento que estimulem a tomada do risco tecnológico, cuja criaçáo deve ser encaminhada simultaneamente.

A contribuição das demais políticas públicas será importante para viabilizar a reorientação das estratégias das empresas industriais. Em particular, será fundamental uma política educacional que busque a universalização do ensino básico e a elevação de sua qualidade, privilegie a formação de cidadãos bem informados e trabalhadores qualificados; e 
uma política trabalhista que estimule a associação nos ganhos e responsabilidades, ao invés do conflito e da desconfiança.

\section{Referências bibliográficas}

ARAÚJO JR., J.T.; CORREA, P.G. \& CASTILHO, M.R. Oportunidades estratégicas da indústria brasileira nos anos 90 . Série Documentos n. 06. Rio de Janeiro, Instituto de Economia Industrial - UFRJ, 1992.

BELL, M. Learning and the accumulation of industrial technological capacity in developing countries. In: N.M. Fransman \& K. King (eds.) Teclonological capability in the Third World. Londres, MacMillan, 1984.

BERGGREN, C. New production concepts in final assembly - the Swedish experience. In: S. Wood, op. cit, 1989.

BRASIL - Secretaria de Ciência e Tecnologia. A politica brasileira de ciência e tecnologia 1990/95. Brasília, SCT, 1991.

BUCHANAN, D.A. \& BODDY, D. Advanced technology and the quality of the working life: the effects of computarised controls on biscuit making operators. Journal of Occupational Psychology, n.56, 1983.

CARDOSO, F.H. As classes nas sociedades capitalistas contemporâneas notas preliminares. Revista de Economia Politica, v.2/1, n.5, jan./mar. 1982.

CARVALHO, R.Q. Why the market reserve is not enough: lessons from the diffusion of industrial automation technology in Brazilian process industries. In: Schmitz, H. \& Cassiolato, J. (1992) op.cit., 1992a.

. Still the old division of labour: programmable automation and patterns of use of labour in Brazilian industry. Tese de doutoramento a ser submetida ao Institute of Development Studies/University of Sussex, Brighton, 1992b.

Do Estado-produtor ao Estado-promotor: fundamentos de uma política industrial sustentada no dinamismo tecnológico. Campinas, Departamento de Política Científica e Tecnológica, IG/UNICAMP, 1992c (mimeo).

L\&PM Editores, 1987.

Tecnologia e trabalho industrial, Sáo Paulo/Porto Alegre,

CARVALHO, R.Q. \& SCHMITZ, H. O fordismo está vivo no Brasil. Novos Estudos, n.27, São Paulo, Cebrap, julho 1990.

CORIAT, B. L'atelier et le robot. Paris, Christian Bourgois, 1990.

CORIAT, B. \& ZARIFIAN, P. Automatisation: filieres d'emploi et recomposition des categories de main-d'oeuvre. Travail, n. 8, Paris, June, 1985. 
COUTINHO, L. \& SUZIGAN, W. (Coord.). Desenvolvinento tccnológico da induistria e a constituigão de um sistema nacional de inovafáa, Săo Paulo, IE/UNICAMP e IPT, 1991.

DAHLMAN, C. Impact of technological change on industrial prospects for the LDCs. Industry Series Paper, n.12, World Bank, June, 1989.

DAVIES, A. Industrial relations and new technology. London, Croom Helm, 1986.

DAHLMAN, C. \& FRISCHTAK, C.R. National systems supporting technical advance in industry: the Brazilian experience. Industry and Energy Department Working Paper - Industry Series Paper, n.32, The World Bank, June, 1990.

DOSI, G. Technological paradigms and technological trajectories: a suggested interpretation of the determinants and directions of technical change. Research Policy, v.11, 1982, p.147-162.

DOSI, G. Technical change and industrial transformation - the theory and an application to the semiconductor industry, London, MacMillan, 1984.

DOSI, G.; FREEMAN, C.; NELSON, R; SILVERBERG, G. \& SOETE, L. (eds.). Technical change and economic theory. IFIAS Rescarchs Series, n.6, Londres/Nova Iorque, Printer, 1988.

EDQUIST, C. \& JACOBSSON, S. Flexible automation: the global diffusion of new technology in the engineering industry. Oxford, Basil Blackwell, 1988.

ENOS, J.L. The creation of technological capability in developing countries. Estudo preparado para a Organização Internacional do Trabalho. Londres/Nova Iorque, Pinter, 1988.

ENOS, J.L. \& PARK, W.H. The adoption and diffusion of imported teclonology: the case of Korea. Beckenham, Croom Helm, 1988.

FLEURY, A. \& HUMPHREY, J. Recursos Humanos e a difusão e adaptaftio de novos métodos para a qualidade no Brasil. Texto apresentado no Seminário Internacional Novas Formas de Gestäo para a Qualidade e Produtividade, Brasília, IPEA, maio, 1992.

FRANSMAN, M. Technology and economic development, Brighton, Bheatsheaf, 1986.

FREEMAN, C. The factory of the future: the productivity paradox, Japanese just-in-time and information technology. PICT Policy Researcls Papers, n.3 London, Economic and Social Research Council, 1988.

FREEMAN, C. \& SOETE, L. (eds.). Technical cbange and full employment, Oxford: Blackwell, 1988.

FREEMAN, C.; CLARK, J. \& SOETE, L. Unemployment and teclmical innovation: a study of long waves in economic development. London, Pinter, 1987. 
FURTADO, A.; COSTA, M.C.; GITAHY, L.; QUEIROZ, S. \& SALLES, S. Capacitafáo tecnologica, politica industrial c competitividade: ima abordagem setorial e por empresas líderes. Relatório de pesquisa apresentado ao IPEA, Campinas, março 1992 (mimeo).

GAZETA MERCANTIL O futuro da indústria. Rclatório Espccial, $31 \mathrm{dez}$. 1991 e Pesquisa de empresa de consultoria, 27 jul. 1992, p.7.

GERSHUNY, J.I. \& MILES, I.D. The new service economy - the transfornation of employment in industrial societies, Londres, Pinter, 1983.

GITAHY, L. \& RABELO, F. Educaçáo e desenvolvimento tecnológico: o caso da indústria de autopeças. Textos para discussão n 11, DPCT/IG, Campinas, Universidade de Campinas, 1991.

HEWITT, T. Employment and skills in the electronics industry: the case of Brazil. Tese (Doutoramento), Brighton, The Institute of Development Studies, University of Sussex, 1988.

HOFFMAN, K. \& RUSH, H. Microelectronics and the garment industry: not yet a perfect fit. IDS Bulletin, v.13, n.2, March 1982.

Microelectronics and clothing - the impact of technical change on a global industry. Science Policy Research Unity, University of Sussex, 1984.

HOFFMAN, K. \& KAPLINSKY, R. Driving force: the global restructuring of technology, labor, and investment in the automobile and components industry, Boulder Colorado/London, Westview Press/UNCTC, 1988.

HUMPHREY, J. Japanese methods and the changing position of dircct production workers: evidence from Latin America. Brighton, IDS/University of Sussex, 1991.

. Nen production methods and labour flexibility in Brazil.

Paper presented to seminar on "Transformación Industrial-produtiva y Relaciones Industriales: América latina y Europa en una Visión Comparativa", Puebla, Mexico, May 1992.

IPEA - Instituto de Pesquisa Econômica Aplicada. Pesquisa Nacional de Avaliaģa do Perfil Cognitivo da Populaf̧a - Projeto de Pesquisa. Brasília, IPEA, 1991, (mimeo).

JURGENS, U.; DOHSE, K.; \& MALSCH, T. New production concepts in West German car plants. In: S. Tolliday \& J. Zeitlin, op. cit., 1986, p.258-281.

KAPLINSKY, R. Restructuring the capitalist labour process: some lessons from the car industry. Cambridge Journal of Economics, v.12, 1988, p.451-470

KERN, H. \& SCHUMANN, M. Vers une professionalisation du travail industriel. Sociologie du Travail, n.4/84, Dunod, Montrouge, Oct./Dec. 1988, p. 398-407. 
KERN, H. \& SCHUMANN, M. Limits of the division of labour. New production and employment concepts in West German industry. Economic and Industrial Democracy, v.8, London, Sage, 1984, p.151-170.

SOFI, 1991 (mimeo).

Rationalization and work in Gcrnan industry. Gottingen,

LAPLANE, M.F. Competitive assessment of Brazilian industrial robots and computer numerical control industries. Campinas, Instituto de Economia, UNICAMP, 1988 (mimeo).

MALSCH, T.; DOHSE, K. \& JURGENS, U. Industrial robots in the automobile industry: a leap towards " automated fordism" ?. IIVG/dp, 84/222, International Institute for Comparative Social Research/labour policy, Berlin, Wissenschaftszentrum, 1984.

MARSDEN, D.; MORRIS, T.; WILLMAN, P. \& WOOD, S. The car industry - Labour relations and industrial adjustment, London/New York, Tavistock Publications, 1985.

NORTHCOTT, J. \& WALLING, A. The impact of microelectronics - diffusion, benefits and problems in British industry. London, Policy Studies Institute, 1988.

OIT - International Labour Office. Productivity and new production processes in the metal trades and their effect on employment and conditions of cmployment. Report of the Twelfth Session of the Metal Trades Committee. Geneva, ILO, 1988.

PAULINYI, E. Empresa nacional - panorama do setor empresarial em 1983. Revista Brasileira de Tecnologia, v.15, n.3, 1984.

PIORE, M.J. \& SABEL, C. The second industrial divide: possibilitics for prosperity, New York, Basic Books, 1984.

POSTHUMA, A. C. Japanese production teclmiques in Brazilian automobile components firms: a best practice model or basis for adaptation. Paper presented at the Conference on the Organisation and Control of the Labour Process, Aston University, Birmingham, March, 1990.

PRADO, A.J.C. A difusão da automação microeletrônica na indústria de auto-peças brasileira e seus impactos sócio-económicos. Caractcrização e indicadores de Automafắ, São Paulo, DIEESE/FINEP, 1989.

SCHMITZ, H. Automação microeletrônica e trabalho: a experiência internacional. In Schmitz, H. \& Carvalho, R.Q. (org.) Automafáto, competitividade e trabalho: a experiencia internacional, São Paulo, Hucitec, 1988.

SCHMITZ, H. Technology and employment practices in developing countries. London, Croom Helm, 1985.

SCHMITZ, H. \& CASSIOLATO, J. Hi-tech for industrial development - lessons from the Brazilian experience in electronics and automation, London $/ \mathrm{New}$ York, Routledge, 1992. 
SCHUMANN, M. New forms of work organization in West German industrial enterprises In: M. Schumann; V. Baethge; U. Neumann \& R. Springer: Breite diffusion der neuen produktionskonzepte - zoegerlicher wandel der arbeitersstrukturen. Soziale Welt n.l, SOFI, University of Goettingen, 1990.

SILVA, E.B. Labour and technology in the car industry: Ford strategies in Britain and Brazil. $\mathrm{PhD}$ thesis. London, University of London, 1988.

SORGE, A.; HARTMANN, G.; WARNER, M. \& NICHOLAS, I. Microelectronics and manpower in manufacturing, Gower, Aldershot, 1983.

VOLPATO, G. The automobile industry in transition: product market changes and firm strategies in the 1970s and 1980s. In: S. Tolliday \& J. Zeitlin (eds.). The automobile industry and its workers, Cambridge, Polity Press, 1986, p. 193-223.

WATANABE, S. Microelectronics, automation and employment in the automobile industry. Chichester, John Willey, 1987.

\section{Notas}

1 Entre os autores que apontam para a revalorização do trabalho, a reprofissionalização e a perda de funcionalidade do paradigma taylorista nas novas condiçōes de produção Schmitz \& Cassiolato, (1992); Coriat, (1990); Kern \& Schumann, (1987) estāo entre os mais difundidos no Brasil. Outros autores chegaram a formular teorias mais compreensivas, em que a reversão da tendência à fragmentação do trabalho é colocada no centro do que seria uma ruptura na história do capitalismo industrial, equivalente em importância, por exemplo, à passagem do artesanato para a manufatura. Neste sentido, talvez a demarche mais conhecida seja The second industrial divide, de Piore Sabel (1984). O sistema desenvolvido por Kaplinsky (Kaplinsky, 1988; Hoffman \& Kaplinsky, 1988), que apresenta o momento atual como de constituição da era da sistemofatura, sucedendo à era da maquinofatura, é igualmente abrangente.

2 Para interpretação histórica dessa mudança, com ênfase nos setores químico c eletroeletrónico, ver Freeman et alii (1982). Sobre o caráter endógeno, cumulativo e apropriável das principais trajetórias de inovação tecnológica no capitalismo contemporâneo, Dosi (1984).

3 A OIT (1988), por exemplo, reporta que nos setores tradicionais da indústria metal-mecânica de algumas economias da OCDE, a atividade de $\mathrm{P \& D}$ tem crescido significativamente. Nas indústrias de material de transportes e construção naval suecas, a participaçăo dos gastos $\mathrm{em} P \& D$ com relação ao faturamento subiu de $13,3 \%$ e $1,7 \%$, respectivamente, para $19,4 \%$ e $4 \%$, entre 1980 e 1984.

4 Os economistas neo-schumpeterianos, e particularmente aqueles oriundos do SPRU (Science Policy Research Unit) da Universidade de Sussex, compóem o grupo de analistas que mais consistentemente exploraram ás implicaçóes da revoluģno microeletrônica para as economias avançadas. Ver Free- 
man \& Soete (1987), para discussão abrangente e empiricamente documentada das novas indústrias e serviços baseados na TI, e de como esta tem afetado as demais indústrias. Ver Dosi (1982) e Dosi et alii (1988), sobre o conceito de paradigma tecnológico. Para análise ampla e empiricamente documentada da experiência brasileira com a TI, ver Schmitz \& Cassiolato (1992).

5 Os NICs asiáticos, e particularmente Coréia do Sul e Taiwan, também souberam aproveitar as oportunidades da TI. Escolhendo momento e estratégia adequados para entrada, constituíram complexos eletrônicos de porte considerável. É significativo que, hoje, os semicondutores (incluindo os sofisticados semicondutores de alta memória) tenham se tornado o principal item isolado de exportação da Coréia do Sul, devendo totalizar US\$ 7 bilhões de exportações neste ano (Gazeta Mercantil, 08/07/92).

6 Entre os inúmeros autores que chamaram a atenção para este ponto, estáo Schmitz (1985 e 1988), Coriat (1990), Kaplinsky (1988), Kern \& Schumann (1987) e Schumann (1990). Há também vasta literatura de caráter mais normativo na área de Administração, sobre o mesmo tema.

7 Estes mesmos pontos são discutidos com detalhe em Carvalho (1992b, capítulo II).

8 Estou considerando como trabalhadores diretos aqueles encarregados de tarefas diretamente relacionadas com a operação de processos produtivos (operação/controle de equipamentos ou ferramentas, alimentação ou monitoramento de máquinas automáticas, montagem ou manipulação de componentes ou materiais etc.). Em contrapartida, as tarefas dos trabalhadores indiretos são todas aquelas que se referem à manutençăo/transformaçăo das condições gerais para a produção (desde tarefas de manutenção até às relativas a pesquisa e desenvolvimento de novos processos e produtos).

9 Ver Northcott \& Walling (1988) para o caso da indústria da Grā-Bretanha. Para exemplos baseados na situação da indústria automobilística européia, Jurgens et alii (1986), Volpato (1986) e Marsden et alii (1985).

10 Para referência mais pormenorizada desse debate, ver o artigo de Fernando Henrique Cardoso (1982), no qual apresenta evidências empíricas da mudança da estrutura de classes nas sociedades avançadas e discute suas implicaçốes para as dinâmicas social e política. Para abordagem detalhada da economia dos serviços e suas implicaçōes sociais, Gershuny \& Miles (1983).

11 Trata-se dos setores automobilístico, máquinas-ferramenta e química.

12 Não cabe aqui examinar em detalhe as características que distinguiram a industrialização por substituição de importaçōes no Brasil. Para discussão da política industrial que conduziu àquele processo e de suas implicaçōes para a competitividade da indústria brasileira, ver Carvalho (1992c).

13 Sobre o conceito de capacitação tecnológica e os estágios da assimilação efetiva de tecnologias, ver Bell (1984), Fransman (1986), Enos \& Park (1988) e Enos (1991). 
14 Para ilustração deste ponto, ver Carvalho (1992a), que discute a fragilidade tecnológica na indústria petroquímica brasileira a partir de survcy $\mathrm{cm} 18$ empresas.

15 O estudo baseia-se em dados de um survey de 1983 (Paulinyi, 1983).

16 No caso específico do investimento em $P \& D$, deve-se acrescentar que as características das modalidades de financiamento disponíveis no Brasil terminam por consolidar a retração da iniciativa empresarial. Ao contrário do Brasil, nos países em que a iniciativa privada tem investido substancialmente em $P \& D$, conta-se com um diversificado leque de opçóes de financiamento e de capitalização que viabilizam a oferta de capital a baixo custo para compensar o risco tecnológico.

17 A densidade de uso corresponde à razão entre o estoque de equipamentos (em unidades) e o número de trabalhadores empregados (em milhōes) nas indústrias mecânica, de material elétrico e de transporte (enginecring industries) em 1980. Para maiores detalhes ver Edquist \& Jacobsson (1988). Para dados mais atualizados envolvendo outros países de industrialização recente, Carvalho (1992b, capítulo 3).

18 Sobre as características qualitativas da incorporação da automação programável na indústria brasileira nos anos 80 , ver Prado (1989) para o caso do setor de auto-peças, Hewitt (1988) para a indústria de bens de informática e Carvalho (1987 c 1990) para a indústria automobilística. Laplane (1988) apresenta avaliação semelhante.

19 Como me sugere André Furtado, esta baixa participação é ainda mais significativa (e intrigante) quando se leva em consideração que o estoque de cientistas e engenheiros formados no Brasil é um dos maiores entre os países de industrialização recente (acima de 1350 mil, de acordo com o Anuário Estatístico da Ứnesco de 1988).

20 Ver Silva (1988) para interpretação mais otimista, baseada no caso da Ford São Bernardo.

21 Gitahy \& Rabello, estudando empresas do setor produtor de auto-peças no Brasil, identificaram duas empresas líderes, que ampliaram suas exportaçóes, como tendo elevado o perfil de escolaridade de sua mão-de-obra. Isto parece ter sido efeito da açăo combinada de dois fatores: maior corte nos quadros com baixa escolaridade nas situações de demissóes coletivas, e exigência de escolaridade mais elevada como critério de recrutamento. Ainda assim, a participação de trabalhadores que náo foram além do primeiro grau completo no total da força de trabalho era de $72 \%$ em um dos casos e de $63 \%$ em outro (Gitahy \& Rabello 1991, tabela 7, p.22).

\section{Resumo}

No artigo procura-se documentar e discutir a relaçăo existente entre atraso tecnológico e uso predatório do trabalho, traçando um paralelo entre o Brasil e os países de industrialização avançada. Na atual fase de aceleração tecnológica, a ampliaçāo do conteúdo inovativo do trabalho é o eixo comum da mudança dos processos de trabalho e constitui importante 
colaboraçáo à capacidade das firmas de acumularem conhecimento e inovarem. No entanto, no Brasil, uma industrialização marcada pelo baixo grau de capacitação tecnológica continua associada à predominância de processos de trabalho ainda inspirados em princípios tayloristas, baseados primordialmente no uso de força de trabalho pouco qualificada, mal remunerada e com vínculo de emprego instável. Argumenta-se que esses dois aspectos do atraso brasileiro reforçam-se mutuamente.

\begin{abstract}
The purpose of this article is to discuss the links between technological backivardness and the advanced industrialised countries. In the current acceleration of technical change, the content of work tends to be enlarged, to incorporate an innovative componet. Such re-valuation of the intelligence of work is an important source for firm's innovative capability. However, in Brazil, industrialisation has been characterised by a low degree of development of technological fragility reinforces (and is reinforced by) the dominance of taylorism principles in the organisation of work, and the use of a workforce which is, generally, little skilled, badly paid and subject to high turnover.
\end{abstract}

Ruy de Quadros Carpalbo é professor do departamento de Política Científica e Tecnológica do Instituto de Geociências da Unicamp (Universidade Estadual de Campinas).

O autor agradece a Renato Dagnino e André Furtado, do DPCT/IG da Unicamp, pela leitura criteriosa que fizeram de uma primeira versão deste texto. 